Article

\title{
Impacts of Future Climate Changes on Spatio-Temporal Distribution of Terrestrial Ecosystems over China
}

\author{
Shuaishuai Li ${ }^{1,2}{ }^{\oplus}$, Jiahua Zhang ${ }^{1,2,3, *(\mathbb{D})}$, Sha Zhang ${ }^{1,2}$, Yun Bai ${ }^{1,2}$, Dan Cao ${ }^{2,3}$, Tiantian Cheng ${ }^{1} \mathbb{C}_{\text {, }}$ \\ Zhongtai Sun ${ }^{1}{ }^{\mathbb{D}}, \mathrm{Qi} \mathrm{Liu}^{3}$ and Til Prasad Pangali Sharma ${ }^{2,3}$ \\ 1 Remote Sensing Information and Digital Earth Center, College of Computer Science and Technology, Qingdao \\ University, Qingdao 266071, China; 2019025922@qdu.edu.cn (S.L.); zhangsha@qdu.edu.cn (S.Z.); \\ baiyun@qdu.edu.cn (Y.B.); 2019025915@qdu.edu.cn (T.C.); sunzhongtai122@gmail.com (Z.S.) \\ 2 Key Laboratory of Digital Earth Science, Aerospace Information Research Institute, Chinese Academy of \\ Sciences, Beijing 100094, China; caodan@radi.ac.cn (D.C.); tilsharma@radi.ac.cn (T.P.P.S.) \\ 3 College of Earth and Planetary Sciences, University of Chinese Academy of Sciences, Beijing 100049, China; \\ liuqi203@mails.ucas.ac.cn \\ * Correspondence: zhangjh@radi.ac.cn; Tel.: +86-10-8217-8122
}

Citation: Li, S.; Zhang, J.; Zhang, S.; Bai, Y.; Cao, D.; Cheng, T.; Sun, Z.; Liu, Q.; Sharma, T.P.P. Impacts of Future Climate Changes on Spatio-Temporal Distribution of Terrestrial Ecosystems over China. Sustainability 2021, 13, 3049. https:// doi.org/10.3390/su13063049

Academic Editor: Carlos Sanz-Lazaro

Received: 4 February 2021

Accepted: 8 March 2021

Published: 10 March 2021

Publisher's Note: MDPI stays neutral with regard to jurisdictional claims in published maps and institutional affiliations.

Copyright: (c) 2021 by the authors. Licensee MDPI, Basel, Switzerland. This article is an open access article distributed under the terms and conditions of the Creative Commons Attribution (CC BY) license (https:// creativecommons.org/licenses/by/ $4.0 /)$.

\begin{abstract}
Understanding the response of terrestrial ecosystems to future climate changes would substantially contribute to the scientific assessment of vegetation-climate interactions. Here, the spatiotemporal distribution and dynamics of vegetation in China were projected and compared based on comprehensive sequential classification system (CSCS) model under representative concentration pathway (RCP) RCP2.6, RCP4.5, and RCP8.5 scenarios, and five sensitivity levels were proposed. The results show that the CSCS model performs well in simulating vegetation distribution. The number of vegetation types would increase from 36 to 40 . Frigid-perhumid rain tundra and alpine meadow are the most distributed vegetation types, with an area of more than $78.45 \times 10^{4} \mathrm{~km}^{2}$, whereas there are no climate conditions suitable for tropical-extra-arid tropical desert in China. Some plants would benefit from climate changes to a certain extent. Warm temperate-arid warm temperate zone semidesert would expand by more than $1.82 \%$ by the $2080 \mathrm{~s}$. A continuous expansion of more than $18.81 \times 10^{4} \mathrm{~km}^{2}$ and northward shift of more than $124.93 \mathrm{~km}$ in tropical forest would occur across all three scenarios. However, some ecosystems would experience inevitable changes. More than $1.33 \%$ of cool temperate-extra-arid temperate zone desert would continuously shrink. Five sensitivity levels present an interphase distribution. More extreme scenarios would result in wider ecosystem responses. The evolutionary trend from cold-arid vegetation to warm-wet vegetation is a prominent feature despite the variability in ecosystem responses to climate changes.
\end{abstract}

Keywords: terrestrial ecosystems; potential natural vegetation (PNV); comprehensive and sequential classification system (CSCS); future climate scenarios; sensitivity; China

\section{Introduction}

The interactions between terrestrial ecosystems and climate changes at the regional scale have long received widespread attention from ecologists [1-10]. The International Geosphere and Biosphere Programme (IGBP) has recognized the accurate prediction of global and regional climate changes and their possible impact on ecosystems as a major research objective [11]. Regional and global climate changes driven by anthropogenic emissions of greenhouse gas (GHG) have placed heavy pressure on terrestrial ecosystems through the processes of rising average air temperatures and interannual variability of rainfall in recent decades [12-15]. These anticipated effects pose a great threat to vegetation growth and survival in susceptible regions, especially climate-sensitive and climate-vulnerable vegetation [16-19]. Basically, mature vegetation is a synonym for the final successional stage of vegetation [20]. Potential natural vegetation (PNV) is defined as the expected state of mature vegetation in the current environmental conditions and the absence of human 
intervention [20,21], which has been widely explored to reflect the climate-vegetation interactions [3]. The study of PNV change is essential to predict the potential impacts of climate changes on terrestrial vegetation dynamics and their response to future climate changes at a large scale, which sets the starting point for vegetation-climate relationship research [1,22].

There are many methods to modeling PNV response to climate changes at the regional and global scales [23-25]. The representative models, such as the "Holdridge life zone" (HLZ) model and the BIOME series models (BIOM1, BIOME2, BIOME3, and BIOME4), have been widely applied to explore the PNV on various spatial scales, which enhance our understanding of the relationship between climate and vegetation patterns [5,26-31]. Based on the biotemperature $(B T)$, the annual precipitation $(P)$, and the potential evapotranspiration rate $(P E R)$, the HLZ model sets up a coordinate system, which divides the world into 38 life zones and more than 100 types [32,33]. However, this system does not consider the difference in the quantitative standard between horizontal and mountain zones, and it is still controversial for taking $30{ }^{\circ} \mathrm{C}$ as the upper limit of biological temperature [3]. The BIOME series models, only used in rough biome simulations at a large scale, are equilibrium vegetation models, while the selection of vegetation function models and the evaluations of the performance of model-based simulations are subject to several limitations, both inherent in the models themselves and in the input data utilized to run the models [5,34]. The Lund-Potsdam-Jena dynamic global vegetation model (LPJ-DGVM), a vegetation-atmosphere model, represents large-scale terrestrial vegetation dynamics and provides a way to comprehensively examine the responses of vegetation ecosystems to climate changes, land processes, and atmospheric $\mathrm{CO}_{2}$ increases $[29,30,35]$. Nevertheless, these benefits have been largely constrained by the complex input parameters required and a lack of data for validation, and further improvement of the DGVM is therefore necessary [12,36]. The comprehensive sequential classification system (CSCS), based on the relationships of climate, soil, and vegetation, was proposed by Ren et al. $[35,37,38]$ in accordance with moisture and heat conditions of the current environment. The model has been successfully applied to simulate biomes at multiple spatial scales, which could contain a greater amount of information. For example, it can reflect the genetic relationship and zonal rules and unify a standard classification [1,13,38,39].

The fifth report of the Intergovernmental Panel on Climate Change (IPCC-AR5) has predicted that the resilience and adaptability of many climate-sensitive ecosystems, by the mid-21st century and beyond, could suffer and experience an unparalleled challenge posed by climate changes coupled with associated disturbances [40]. There are various thermal and humidity zones in China, and the diversity in climate environments has bred rich vegetation types $[40,41]$. In the context of global climate changes, the vegetation in China would also undergo adaptive changes in distribution and growth [3]. Therefore, the projection of the PNV change is of great significance to alleviate and effectively adapt to the impacts of climate changes on terrestrial ecosystems in China. The representative concentration pathways (RCPs) implemented by the IPCC-AR5 provided a long time series, in the range of historical to the future, for global land areas at a very high spatial resolution [42]. Combined with the CSCS method, the data have been successfully applied to simulate climate changes and their effects on terrestrial ecosystems. Numerous studies have been conducted on PNV in China based on the CSCS model. For instance, based on the CSCS model, Xiu et al. [43] carried out a study on the distribution dynamics of PNV in China using meteorological station data (1981-2010), coupled with future climate data (the 2030s, 2050s, and 2080s) under the RCP scenarios issued by the IPCC-AR5. Du et al. [11] explored the spatio-temporal distribution of PNV by using meteorological station data (1986-2015) and climate data (the 2030s, 2050s, and 2080s) under RCP4.5 scenarios as inputs into the CSCS model, and they divided its sensitivity to climate changes into four levels. Nevertheless, it is with high confidence that the number and uniform distribution of meteorological stations are expected to both directly and indirectly affect the interpolation effect of data, with consequences of biased results. Recently, based on the 
CSCS model, in combination of climatic datasets in the period of last interglacial period, etc., and projected data in the 2050s and 2070s under RCP2.6, the PNV and its response to climate changes were analyzed by Ren et al. [44]. However, these previous efforts have been mostly based on a single future climate scenario or biased data provided by the interpolation method; few have tried to conduct future intercomparison studies on the spatio-temporal succession of PNV in China and its sensitivity to climate changes under different RCPs. In addition, detailed comparisons between the CSCS model, the HLZ model, and a map of actual vegetation at a national scale have only been implemented minimally. Therefore, considering climate changes and the possible extent of their impacts on vegetation ecosystems in China, covering long time series under different climate scenarios, is essential to fill the gaps in this field.

This study aims to simulate terrestrial vegetation under projected climate changes across China at a 30 arc-s resolution ( 1 km resolution), in particular with the dynamics of the spatio-temporal distribution of PNV and its succession as a consequence of climate changes, coupled with its sensitivity under different future climate scenarios. The objectives of this study are (1) to validate the accuracy of the CSCS model in simulating PNV of China; (2) to produce long time series maps of PNV in China with a 30 arc-s resolution ( 1 km resolution) under current conditions (1970-2000) and future periods, covering the 2030s (2020-2049), 2050s (2040-2069), 2070s (2060-2089), and 2080s (2070-2099) under RCP2.6, RCP4.5, and RCP8.5 scenarios based on the CSCS model; (3) to compare the spatio-temporal distribution of PNV in China under three future climate scenarios; (4) to provide great potential in providing insights into how vegetation ecosystems in China will respond to climate changes in the upcoming decades; (5) to propose several sensitivity levels of PNV in China to climate changes.

\section{Materials and Methods}

\subsection{Study Area}

There are various thermal and humidity zones in China, and extra-arid zones, arid zones, semiarid zones, subhumid zones, humid zones, and perhumid zones dominate different regions in China (Figure 1), and more humid characteristics in China are found successively from northeast to southwest. The diversity in climate results in various vegetation types, and has a remarkable influence on the growth and richness of vegetation [40]. Interactions between vegetation and climate changes would vary in each vegetation type under different climate scenarios.

\subsection{Data}

The four datasets used in this study are current climate data, CPIM5 scenario projected data, basic geographic data, and a map of actual vegetation, as shown in Table 1. 


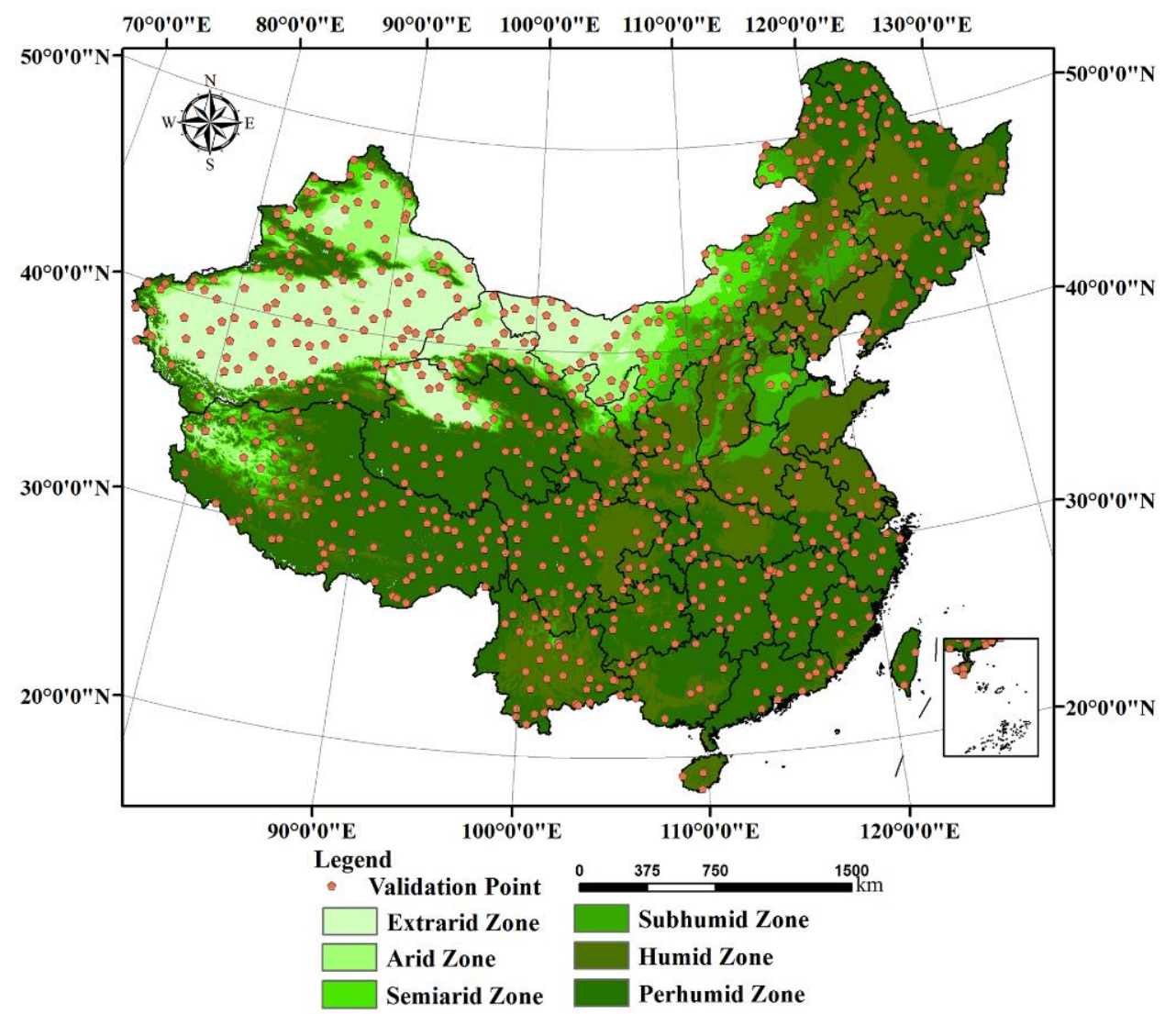

Figure 1. Humidity levels of China and the random validation points (750 samples) are used to verify the accuracy of the comprehensive sequential classification system (CSCS) model.

Table 1. Datasets used in this study.

\begin{tabular}{|c|c|c|c|c|c|c|}
\hline & Scenarios & Time (Year) & Source & $\begin{array}{c}\text { Spatial } \\
\text { Resolution }\end{array}$ & $\begin{array}{c}\text { Temporal } \\
\text { Resolution }\end{array}$ & URL \\
\hline $\begin{array}{l}\text { The current } \\
\text { scenario data }\end{array}$ & - & 1970-2000 & WorldClim 2.1 & 30 arc-s & Monthly & $\begin{array}{l}\text { https://www. } \\
\text { worldclim.org/ } \\
\text { (accessed on } 7 \\
\text { March 2021) }\end{array}$ \\
\hline $\begin{array}{l}\text { The future climate } \\
\text { scenarios data }\end{array}$ & $\begin{array}{l}\text { RCP2.6 } \\
\text { RCP4.5 } \\
\text { RCP8.5 }\end{array}$ & $\begin{array}{l}2050 s(2040-2069) \\
2070 s(2060-2089) \\
2070 s(2060-2089) \\
2080 s(2070-2099)\end{array}$ & MRI-CGCM3 & 30 arc-s & Monthly & $\begin{array}{l}\text { http://ccafs- } \\
\text { climate.org/ } \\
\text { (accessed on } 7 \\
\text { March 2021) }\end{array}$ \\
\hline $\begin{array}{c}\text { China } \\
\text { administrative } \\
\text { division map }\end{array}$ & - & - & $\begin{array}{c}\text { National Natural } \\
\text { Resources Standard } \\
\text { Geographic Service } \\
\text { Network }\end{array}$ & - & - & $\begin{array}{l}\text { http:/ /bzdt.ch.mnr. } \\
\text { gov.cn (accessed on } \\
7 \text { March 2021) }\end{array}$ \\
\hline $\begin{array}{l}\text { A vegetation map } \\
\text { in China at a scale } \\
\text { of } 1: 1,000,000\end{array}$ & - & - & $\begin{array}{c}\text { Resource and } \\
\text { Environment Science } \\
\text { and Data Center }\end{array}$ & $1 \mathrm{~km}$ & - & $\begin{array}{c}\text { http: } \\
\text { //www.resdc.cn/ } \\
\text { (accessed on } 7 \\
\text { March 2021) }\end{array}$ \\
\hline
\end{tabular}

A comparison or reference to climate scenarios that can be used to determine scenarios and climate change projections usually corresponds to the period 1970-2000. Hence, the period 1970-2000 is set as the current scenario, which is obtained from WorldClim 2.1 provided by World Climate Data. This gridded dataset can create finer estimations for month-by-month temperature and precipitation variables with a 30 arc-s resolution $(\sim 1 \mathrm{~km}$ resolution). Particularly, the prediction accuracy for temperature variables improved 5-15\% $\left(0.07-0.17^{\circ} \mathrm{C}\right)$ [42]. The data are employed to drive the CSCS model to simulate PNV under the current scenario. Additionally, the modeling outcomes are used to validate the effect of the CSCS model in simulating PNV at a national scale. 
The four time slices for future climate scenarios of RCP2.6, 4.5, and 8.5 we selected were named 2020-2049 (2030s), 2040-2069 (2050s), 2060-2089 (2070s), and 2070-2099 (2080s). These high-resolution (30 arc-s) and bias-corrected projections are produced by the Meteorological Research Institute Coupled General Circulation Model version 3 (MRI-CGCM3) issued by the IPCC-AR5 [45]. The IPCC-AR5 adopts new emission scenarios (RCPs) including RCP2.6 (the low-level emission scenario), RCP4.5 (the mid-level emission scenario), RCP6.0 (the high-level emission scenario), and RCP8.5 (the higher-level emission scenario) that approximately result in radiative forcing levels of $8.5,6.0,4.5$, and $2.6 \mathrm{~W} / \mathrm{m}^{2}$ by 2100 , relative to pre-industrial conditions [46-49]. The MRI-CGCM3 is more suitable for simulating the seasonal changes of temperature and the north-south distribution differences in precipitation in China [50-52]. In addition, the original output datasets we used at a 30 arc-s resolution ( $\sim 1 \mathrm{~km}$ resolution) containing more information on space and ground objects, which can reduce climate model bias by $50-70 \%[46,53]$. Climate inputs for the mean annual precipitation $(M A P)$ and cumulative annual temperature above $0^{\circ} \mathrm{C}(\Sigma \theta)$ are incorporated from the projected datasets of the mean monthly temperature and precipitation.

The administrative zoning map of China was utilized as a mask to extract the study area.

The vegetation map of China at a scale of 1:1,000,000 was used to validate the CSCS model. It reflected in detail the actual vegetation distribution status in China, and 43 original vegetation types were then aggregated into five broad vegetation types. The map in raster form at a $1 \mathrm{~km}$ resolution is an essential scientific material and an important basis for studying climate changes, biodiversity, and vegetation protection and monitoring.

\subsection{Methods}

\subsubsection{The Potential Natural Vegetation Model}

The CSCS model, proposed by Ren et al. [37], is a comprehensive sequential classification system of climate-soil-vegetation [11]. The system is composed of three levels: class, subclass, and type, which are established through zonal bioclimatic characteristics, namely, the grouping or clustering of units with similar moisture and temperature properties [1,38]. The theory is that vegetation distribution is affected by the bioclimatic conditions, edaphic conditions, and vegetation characteristics, while the bioclimatic conditions are the most stable [11]. Therefore, the class level, the basic unit, is relatively stable and mainly determined by bioclimatic conditions. Classification in terms of the same class is supposed to have a consistent interpretation despite the difference in geographic locations [12]. The subclass level has intermediate stability, and is determined by the edaphic conditions [38]. Subclasses are integrated into classes based on the indexes of moisture and temperature which capture the natural occurrence of vegetation ecosystems [38]. The type level, the "less stable" hierarchy, is based on vegetation characteristics [12,38].

In the class level, the two key inputs employed in the CSCS model are the index of moisture based on humidity $(K)$ and the index of heat based on cumulative annual temperature above $0{ }^{\circ} \mathrm{C}(\Sigma \theta)$ (i.e., growing degree-days on a $0^{\circ} \mathrm{C}$ base, GDD0) [54]. The formula is as follows:

$$
K=M A P / 0.1 \times \Sigma \theta=M A P / 0.1 \times G D D 0
$$

where $M A P$ represents the mean annual precipitation $(\mathrm{mm}) ; \Sigma \theta$ is cumulative annual temperature above $0{ }^{\circ} \mathrm{C} ; 0.1$ is an empirical parameter, and $K$ is the humidity. By considering the relationship between vegetation type, soil type, natural zone, agricultural zone, animal husbandry production type, and contour line of the $K$ value, the humidity is divided into 6 levels [1] (Figure 2). 


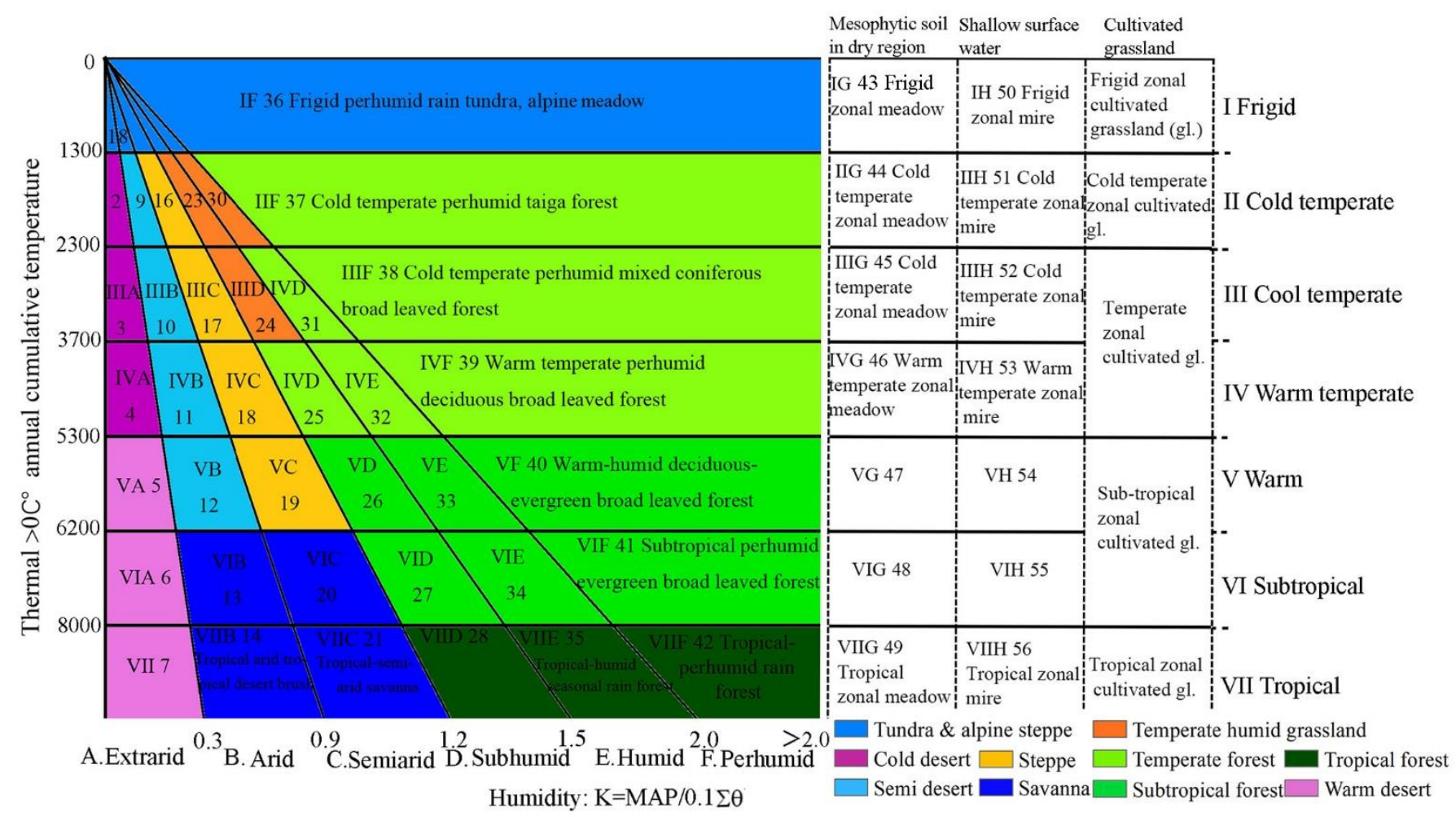

Figure 2. The index chart of the CSCS model.

According to the heat zone distribution, the heat is divided into 7 levels (Figure 1). Fifty-six PNV types can be theoretically classified by 7 thermal and 8 humidity levels (6 humidity levels, 1 meadow level, and 1 swamp level) [1]. To further explore the dynamics of distribution of PNV in China, 56 classes were regrouped into 10 super-classes based on the zonal characteristics. (Table 2) [1]. The overall approach is illustrated in Figure 3.

Table 2. The relationships between super-classes and corresponding class code in the comprehensive sequential classification system (CSCS) model. The corresponding class names of the class codes are shown in Table A1.

\begin{tabular}{ccccc}
\hline Code & Super-Classes & $\begin{array}{c}>\mathbf{0}^{\circ} \mathbf{C} \text { Annual Cumulative } \\
\text { Temperature }(\boldsymbol{\Sigma} \boldsymbol{\theta})\end{array}$ & Humidity $(\boldsymbol{K})$ & Corresponding Class Code \\
\hline 1 & Tundra and alpine & $0-1300$ & $>0$ & IA, IB, IC, ID, IE, IF \\
2 & steppe & $1300-5300$ & $0-0.3$ & IIA, IIIA, IVA \\
3 & Cold desert & $1300-6200$ & $0.3-0.9$ & IIB, IIIB, IVB, VB \\
4 & Semidesert & $1300-6200$ & $0.9-1.2$ & IIC, IIIC, IVC, VC \\
5 & Semperate humid & $1300-3700$ & $1.2-2.0$ & IID, IIID, IIE \\
6 & grassland & $1300-5300$ & $>1.2$ & IVD, IIIE, IVE, IIF, IIIF, IVF \\
7 & Temperate forest & $5300-8000$ & $>1.2$ & VD, VID, VE, VIE, VF, VIF \\
8 & Trotropical forest & $>8000$ & $0-0.3$ & VIID, VIIE, VIIF \\
9 & Warm desert & $>5300$ & $0.3-1.5$ & VA, VIA, VIIA \\
10 & Savanna & $>6200$ & & VIB, VIIB, VIC, VIIC \\
\hline
\end{tabular}




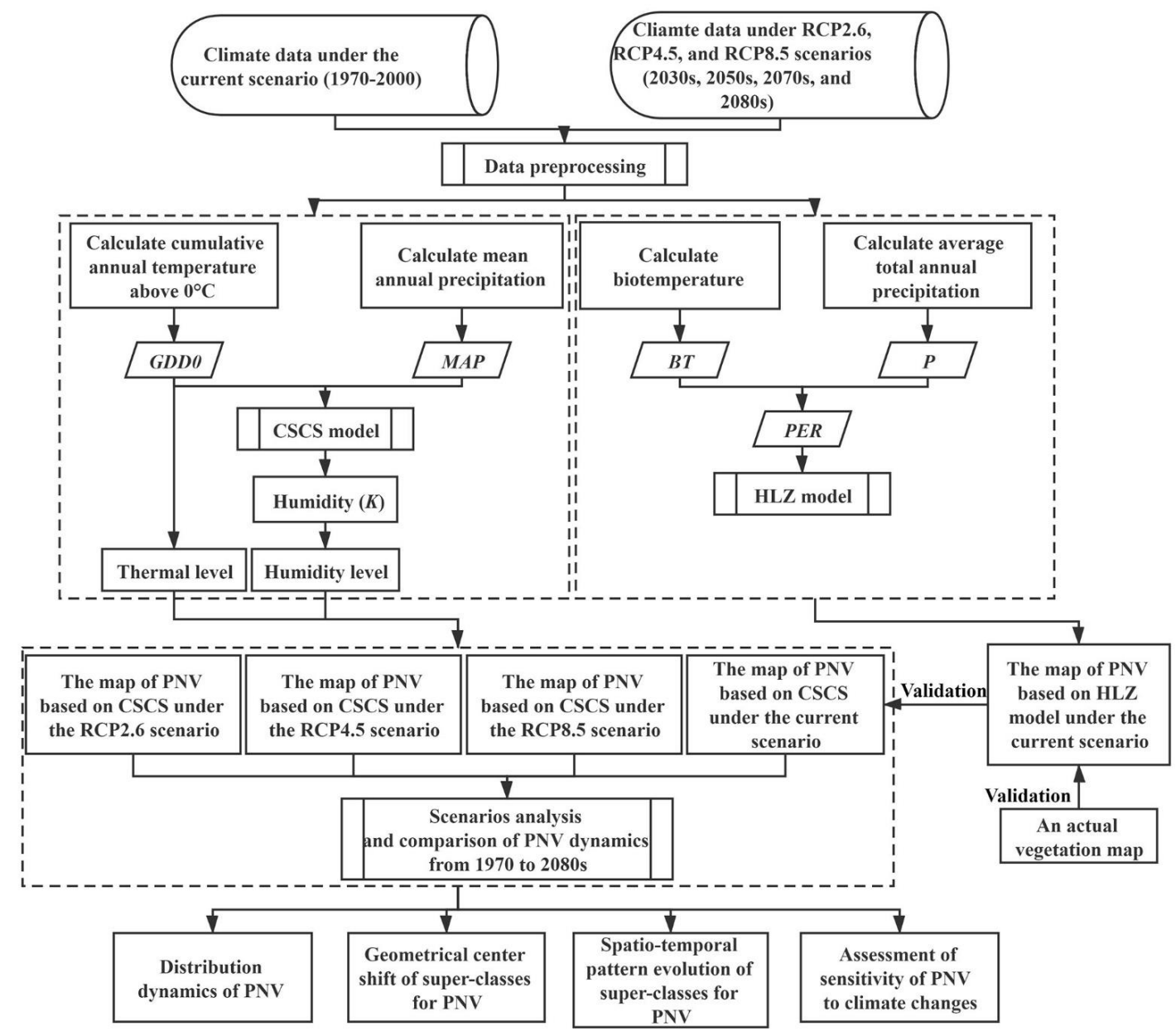

Figure 3. The flowchart of potential natural vegetation (PNV) simulation based on the CSCS model. HLZ is Holdridge Life Zone" and RCP is Representative Concentration Pathways.

\subsubsection{The Holdridge Life Zone Model}

The HLZ model divides the world into over 38 life zones to determine the distribution of potential terrestrial ecosystems based on biotemperature (BT), average total annual precipitation $(P)$, and potential evapotranspiration ratio $(P E R)[28,33]$. The specific calculation formula of each HLZ model factor is as follows:

$$
\begin{gathered}
B T=1 / 12 \times \sum_{i=1}^{12} T_{i} \\
P E T=58.96 \times B T \\
P E R=P E T / P=58.96 \times B T / P \\
D_{k}(i, j)=\sqrt{\left[\left(B T(i, j)-B T_{k}\right)\right]^{2}+\left[\left(P(i, j)-P_{k}\right]^{2}+\left[\left(P E R(i, j)-P E R_{k}\right)\right]^{2}\right.}
\end{gathered}
$$

where $T_{i}$ is monthly mean temperature $\left({ }^{\circ} \mathrm{C}\right)$, with values below $0^{\circ} \mathrm{C}$ substituted with $0{ }^{\circ} \mathrm{C}$ and above $30^{\circ} \mathrm{C}$ substituted with $30^{\circ} \mathrm{C}$; BT is mean annual biotemperature $\left({ }^{\circ} \mathrm{C}\right)$; PET is potential evapotranspiration $(\mathrm{mm}) ; P$ is average total annual precipitation $(\mathrm{mm}) ; P E R$ is potential evapotranspiration ratio; $B T(i, j), P(i, j)$, and $P E R(i, j)$, respectively, represent the average annual biological temperature value, annual precipitation value, and possible evapotranspiration rate value of the $i^{\text {th }}$ row and the $j^{\text {th }}$ column grid in the spatial raster data; $B T_{k}, P_{k}$, and $P E R_{k}$ are the central climate indexes of the $k^{\text {th }}$ hexagon in the life zone; 
$D_{k}(i, j)$ is the distance from the center of the hexagon in the $k^{\text {th }}$ Holdridge model to $i^{\text {th }}$ row and the $j^{\text {th }}$ column grid.

\subsubsection{The CSCS Model Validation}

To make direct comparisons between the CSCS model, the HLZ model, and a vegetation map in China at a scale of 1:1,000,000, the following PNV maps in China from 1970-2000 were employed. Firstly, we generated PNV maps with $1 \mathrm{~km}$ spatial resolution based on the CSCS and HLZ model to validate the accuracy of the CSCS model and make appropriate comparisons over the same period. To further assess the capability of the CSCS model and HLZ model in simulating PNV distribution on a national scale, we compared two PNV maps with a vegetation map of China at a scale of 1:1,000,000.

Considering that each PNV type in the HLZ model may not necessarily correspond to one or more PNV types in the CSCS model because of the significant differences between the two models in terms of classification indices and methods, it is crucial for direct comparisons (i.e., CSCS vs. HLZ, CSCS vs. a vegetation map, HLZ vs. a vegetation map) to merge classes. Therefore, after trial and error, we proposed a reclassification where the 10 types of the CSCS model, 38 categories of the HLZ model, and 43 vegetation types (Table A1) were aggregated into the same 5 broad categories based on previous work on accuracy verification of the CSCS model (Table 3) $[43,55]$. Considering that validation samples would involve the majority of the study area and validate the reliability and accuracy of simulation results based on the CSCS and HLZ models well, we randomly created 750 points across China in ArcGIS software (Figure 1).

Table 3. The reclassification of vegetation types in the CSCS model, the HLZ model, and the vegetation map of China at a scale of 1:1,000,000. (a) Super-classes in the CSCS model are found in Table 2; ${ }^{\text {(b) }}$ the class names are found in Table A1.

\begin{tabular}{|c|c|c|c|c|}
\hline Code & Broad Vegetation Types & $\begin{array}{l}\text { Super-Class Code }{ }^{(a)} \text { in } \\
\text { the CSCS Model }\end{array}$ & $\begin{array}{l}\text { Class Code }{ }^{(b)} \text { in the HLZ } \\
\text { Model }\end{array}$ & $\begin{array}{l}\text { Vegetation Code }^{(b)} \text { in the } \\
\text { Vegetation Map }\end{array}$ \\
\hline 1 & Tundra & 1 & $1,2,3,4,5$ & $46,47,48$ \\
\hline 2 & Desert & $2,3,9$ & $\begin{array}{c}6,7,11,12,17,18,19,24,25,31 \\
32\end{array}$ & $25,26,27,28,29,30,31$ \\
\hline 3 & Boreal and temperate forest & 6 & $8,9,10,14,15,16$ & $1,2,6,7,8,9,18,22,23,24$ \\
\hline 4 & $\begin{array}{c}\text { Subtropical and tropical } \\
\text { forest }\end{array}$ & 7,8 & $\begin{array}{c}20,21,22,23,26,27,28,29,30 \\
33,34,35,36,37,38\end{array}$ & $\begin{array}{c}3,4,5,7,10,11,12,13,14,15,16 \\
17,19,20,21,22\end{array}$ \\
\hline 5 & Grassland & $4,5,10$ & 13 & $32,33,34,35,36,37,38,39,40,41$ \\
\hline
\end{tabular}

\subsubsection{The Kappa Statistic}

The Kappa coefficient has been widely used in assessing model-simulated vegetation types and spatial distributions due to its advantages. It takes chance agreement into account, regardless of the number of types being compared in the maps $[5,56]$. We employed the Kappa statistic to evaluate the similarities and validate the accuracy between the two kinds of PNV maps on a national scale. The Kappa statistic is expressed by [57]:

$$
K=\left(N \sum_{i}^{n} p_{i i}-\sum_{i}^{n}\left(p_{i+} p_{+i}\right)\right) /\left(N^{2}-\sum_{i}^{n}\left(p_{i+} p_{+i}\right)\right)
$$

where $N$ is the total number of samples; $n$ denotes the number of rows and columns in the error matrix; $P_{i i}$ represents the individual entry for the row and column on the main diagonal of the constructed error matrix; $P_{i+}$ denotes the row total for each category $i ; P_{+i}$ is the column total for each category $i$.

In general, the Kappa statistic $(k)$ ranges from 0.0 to 1.0 , with 0.0 representing totally different patterns and 1.0 indicating complete agreement. The evaluation thresholds are: $0.0-0.2$ : no to poor agreement; 0.2-0.4: poor to fair agreement; $0.4-0.55$ : fair to good agreement; $0.55-0.70$ : good to very good agreement; $0.7-1.0$ : very good to perfect agreement [35]. 


\section{Results and Discussion}

\subsection{Accuracy Verification Based on the CSCS Model}

To verify that the CSCS model we employed performs well in predicting the vegetation distribution, the differences in the simulation results between the CSCS model and HLZ model are compared and studied. Figure $4 \mathrm{a}$,b show the PNV maps based on simulated CSCS and HLZ models in China for 1970-2000, respectively. It can be seen that the PNV classes are 36 and 30 in the results of the CSCS and HLZ models, respectively. The CSCS and HLZ PNV maps are in good to very good agreement, with an overall Kappa statistic of 0.7 with 750 samples. In another relevant study, Liang et al. [1] also got a similar $K$ value (0.74) through comparing CSCS with HLZ PNV maps with other formulas. The fair to good agreement between the CSCS PNV and the vegetation distribution map at a scale of 1:1,000,000 (overall $K$ value of 0.5 ) is similar to that of the HLZ PNV and the map of actual vegetation (overall Kappa statistic of 0.4 ), both notably less than the good to very good agreement between CSCS and HLZ PNV maps. Moreover, the $K$ value of the CSCS model is higher than the HLZ model. In another relevant studies, Zheng et al. [32] and Yates et al. [58] also calculated similar $K$ values of 0.43 and 0.48 through comparing the actual vegetation map with simulated vegetation distribution from the HLZ model. Therefore, we believed that the CSCS model could lead to reasonably good simulations of vegetation distribution in China, and the CSCS model is superior to the HLZ model.

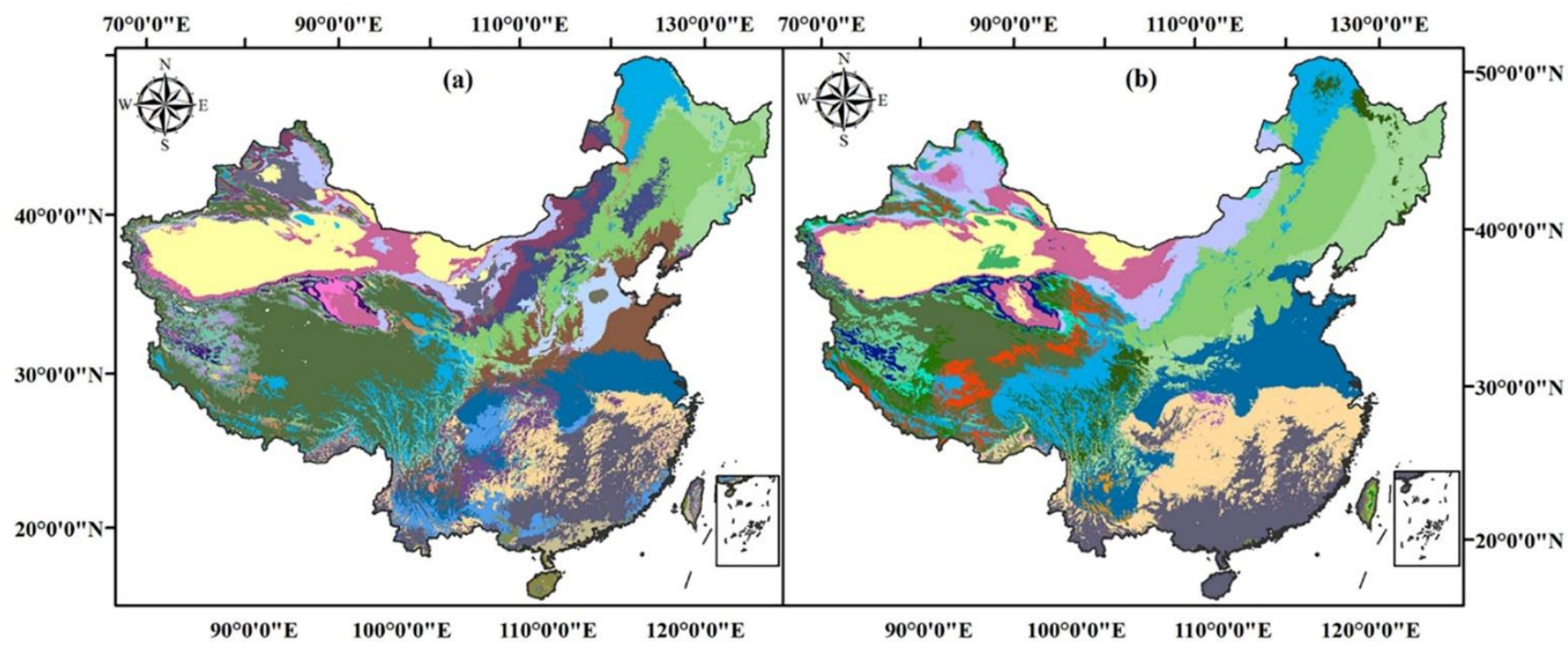

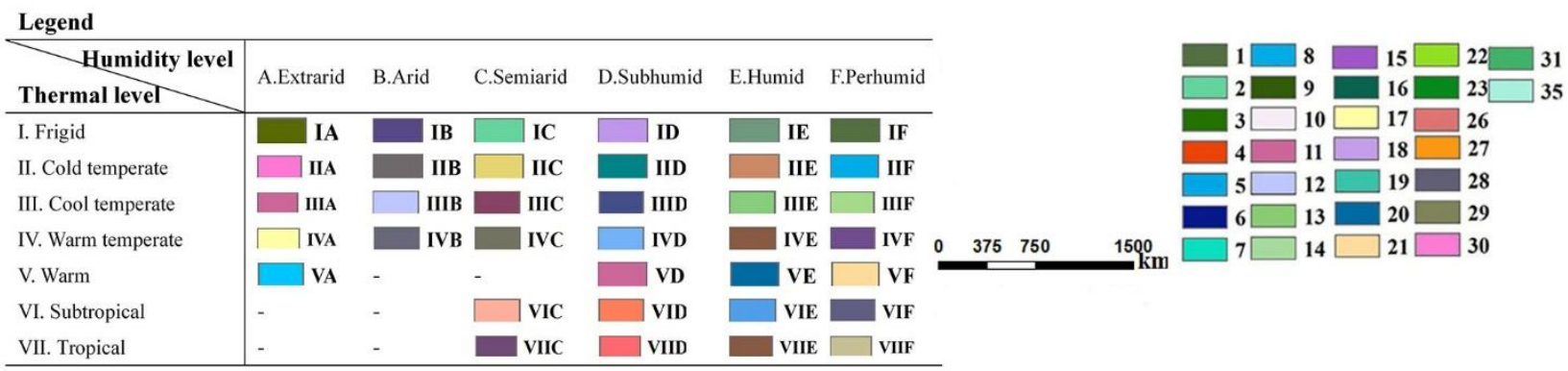

Figure 4. The spatial pattern of PNV in China from 1970 to 2000 based on the (a) CSCS model and (b) Holdridge life zone (HLZ) model. The corresponding class names of the class codes are shown in Table A1 in Appendix A.

\subsection{Spatial Distribution of PNV in China under the Current Scenario}

There were 36 types of PNV in China during the period of 1970-2000 (T0) (Figure 4a and Table A2 in Appendix A), indicating that six types of vegetation, such as the tropicalextra-arid tropical desert (VIIA), did not appear at all in China in T0. The three PNV types with 
a wide distribution area are frigid-perhumid rain tundra, alpine meadow (IF), cool temperatehumid forest steppe, deciduous broad-leaved forest (IIIE), and warm temperate-extra-arid warm temperate zone desert (IVA), with the areas of $149.43 \times 10^{4} \mathrm{~km}^{2}, 92.32 \times 10^{4} \mathrm{~km}^{2}$, and $90.22 \times 10^{4} \mathrm{~km}^{2}$, respectively, covering nearly $15.6 \%, 9.61 \%$, and $9.39 \%$ of the total national area. IF, the most extensively distributed vegetation, is extensively distributed in the cold and wet mountainous areas of the Qinghai-Tibet Plateau, the Tianshan Mountains, and the Altai Mountains. IIIE is centrally distributed on the south side of Xiaoxing'anling, Daxing'anling, and Qinghai Nanshan. IVA is mainly distributed in the Tarim Basin, Inner Mongolia Plateau, and Zhungeer Basin.

\subsection{Spatial Variations of PNV in China under Future Climate Scenarios}

The spatial distribution and areas of PNV in China in the 2030s, 2050s, 2070s, and 2080s (T1, T2, T3, and T4) under three RCPs are shown in Figures 5-7, and Table A2. Our maps indicate that there are 39 (T1, T2 of RCP2.6, and T1 of RCP4.5) or 40 (others) classes of PNV in China. It is worth noting that VIIA does not appear in any periods of the three RCPs, which is consistent with the result of Du et al. [11]. Combined with the outcome of the current scenario, we found that VIIA never appeared in China from T0 to T4 in the four RCPs. Therefore, there is no suitable habitat for VIIA in China. The modeled results showed consistency with $\mathrm{Che}$ et al. [3]. Meanwhile, frigid-extra-arid frigid desert, alpine desert (IA) only appears in T4 of the RCP2.6 scenario with $0.012 \times 10^{4} \mathrm{~km}^{2}$, and subtropical-extra-arid subtropical desert (VIA) is not observed in T1, T2, and T4 of RCP2.6 and T1 of RCP4.5. All the other 39 vegetation types are projected to be distributed in the five periods of the three RCPs; nevertheless, the area changes for each vegetation type show obvious differences.

Specifically, three possible change trends of areas were explored across all periods under the three RCPs, including the expansion, reduction, and fluctuation types (Table 4). Under the three scenarios, warm temperate-arid warm temperate zone semidesert (IVB) would benefit from the future climate, and is predicted to increase continuously. By contrast, the area of cold temperate-extra-arid montane desert (IIA) and cool temperate-extra-arid temperate zone desert (IIIA) would decrease consistently, in which IIA would cover less than $0.01 \%$ of the total land area of China in T3 and T4 under RCP8.5. These vegetation types would suffer and experience irreversible changes caused by climate changes if the radiative forcing level reflects the higher-level emission scenario (RCP8.5) by the end of the century.

Table 4. The change trends of each potential natural vegetation (PNV) area in China.

\begin{tabular}{|c|c|c|c|c|}
\hline & & RCP2.6 & RCP4.5 & RCP8.5 \\
\hline \multicolumn{2}{|c|}{ Expansion pattern } & IVB, VIIE & $\begin{array}{l}\text { IID, IIF, IVB, IVD, VA, VC, } \\
\text { VIA, VID, VIIF }\end{array}$ & $\begin{array}{l}\text { IID, IIF, IVB, IVC, IVD, VIA, } \\
\text { VIB, VIC, VIIC, VIID, VIIE, } \\
\text { VIIF }\end{array}$ \\
\hline \multicolumn{2}{|c|}{ Reduction pattern } & IIA, IIC, IIIA, VF & IIA, IIC, IIIA, IVE, VF & $\begin{array}{l}\text { IA, IB, IC, ID, IE, IF, IIA, IIIA, } \\
\text { IIIE, VF }\end{array}$ \\
\hline \multirow[t]{2}{*}{ Fluctuation pattern } & Expansion of fluctuation & $\begin{array}{l}\text { IB, IE, IIB, IIE, IIF, IIIB, IIIF, } \\
\text { IVA, IVC, VA, VB, VC, VD, } \\
\text { VIB, VIC, VID, VIE, VIF, } \\
\text { VIIB, VIIC, VIID, VIIF }\end{array}$ & $\begin{array}{c}\text { IB, IE, IIB, IIE, IIF, IIIB, } \\
\text { IIID, IIIF, IVC, VB, VD, } \\
\text { VIC, VIE, VIF, VIIB, VIIC, } \\
\text { VIID, VIIE }\end{array}$ & $\begin{array}{c}\text { IIC, IIE, IIIF, VA, VB, VC, VID, } \\
\text { VIE, VIIB }\end{array}$ \\
\hline & Reduction of fluctuation & $\begin{array}{c}\text { IA, IC, ID, IF, IID, IIIC, } \\
\text { IIID, IIIE, IVD, IVE, IVF, } \\
\text { VE }\end{array}$ & $\begin{array}{l}\text { IA, IC, ID, IF, IIIC, IIIE, } \\
\text { IVA, IVF, VE, VIB }\end{array}$ & IIB, IIIB, IIIC, IIID, VE \\
\hline
\end{tabular}




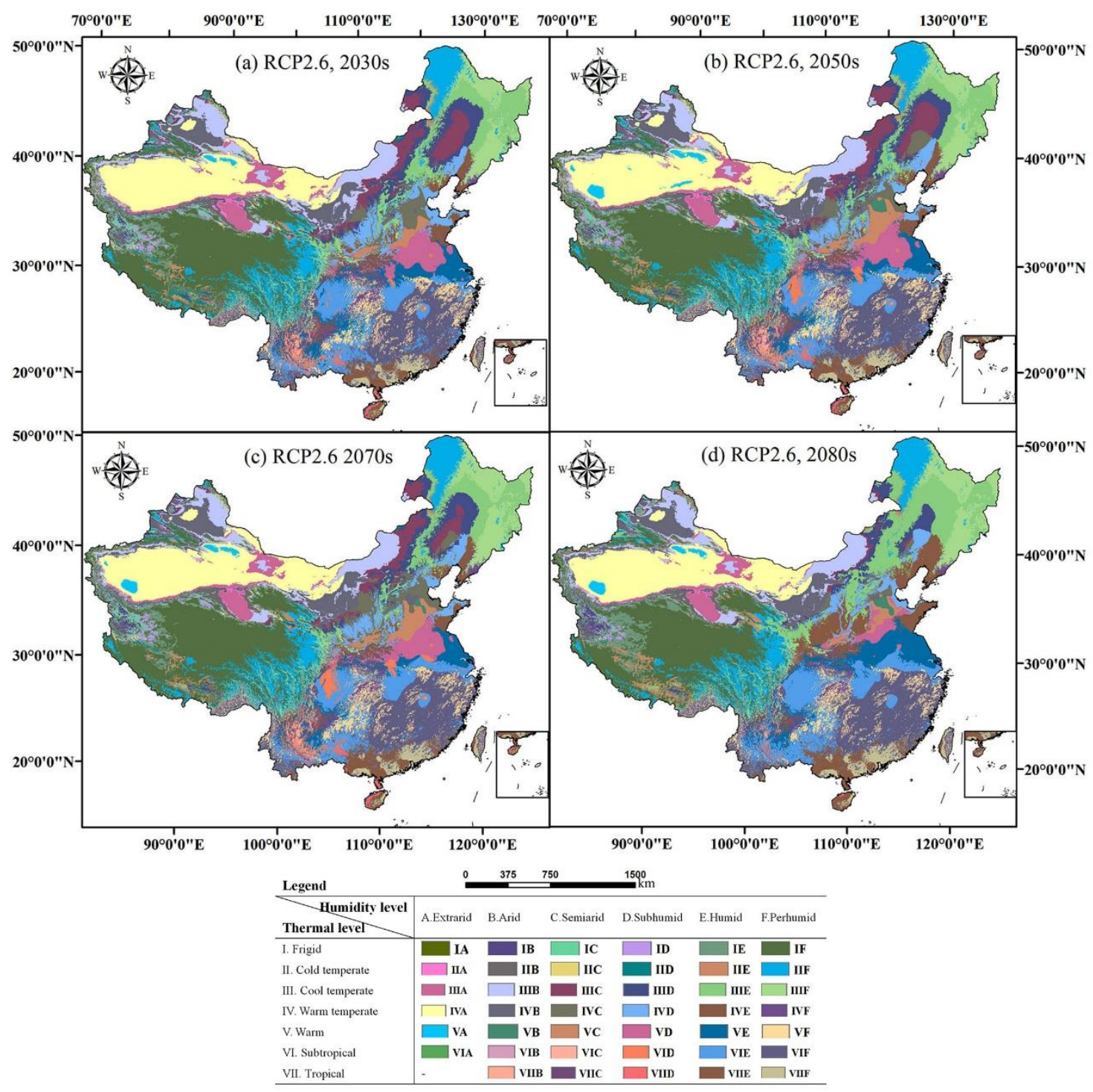

Figure 5. The spatial pattern of PNV in China in the (a) 2030s, (b) 2050s, (c) 2070s, and (d) 2080s of RCP2.6. The corresponding class names of class codes are shown in Table A1 in Appendix A.

Under the RCP2.6 scenario (Figure 5 and Table A2), the greatest continuous decreases are projected for warm-humid deciduous-evergreen broad-leaved forest (VF), followed by cool temperate-extra-arid temperate zone desert (IIIA), of $0.78 \times 10^{4} \mathrm{~km}^{2}$ and $0.48 \times 10^{4} \mathrm{~km}^{2}$ per decade, respectively. By contrast, the distribution of warm temperatearid warm temperate zone semidesert (IVB) and tropical-humid seasonal rain forest (VIIE) would expand continuously by $0.67 \times 10^{4} \mathrm{~km}^{2}$ and $0.50 \times 10^{4} \mathrm{~km}^{2}$ per decade, respectively. In addition, the area of tropical-semiarid savanna (VIIC) and tropical-subhumid tropical xerophytic forest (VIID) would increase, by $38 \%$ and $15.13 \%$, respectively, relative to T0.

Under the RCP4.5 scenario (Figure 6 and Table A2), among all vegetation types, the distribution of warm-humid deciduous-evergreen broad-leaved forest (VF) would consistently shrink the most, followed by warm temperate-humid deciduous broad-leaved forest (IVE), by $1.09 \times 10^{4} \mathrm{~km}^{2}$ and $1.04 \times 10^{4} \mathrm{~km}^{2}$ per decade, respectively. By contrast, the highest and the second highest increases are projected for warm-extra-arid subtropical desert (VA) and warm temperate-arid warm temperate zone semidesert (IVB) of $1.99 \times 10^{4} \mathrm{~km}^{2}$ and $1.13 \times 10^{4} \mathrm{~km}^{2}$ per decade. In addition, the highest increase in area would occur in VIIC by $170.23 \%$ relative to $\mathrm{T} 0$, and VIID is also predicted to expand by $111.48 \%$ relative to T0. 


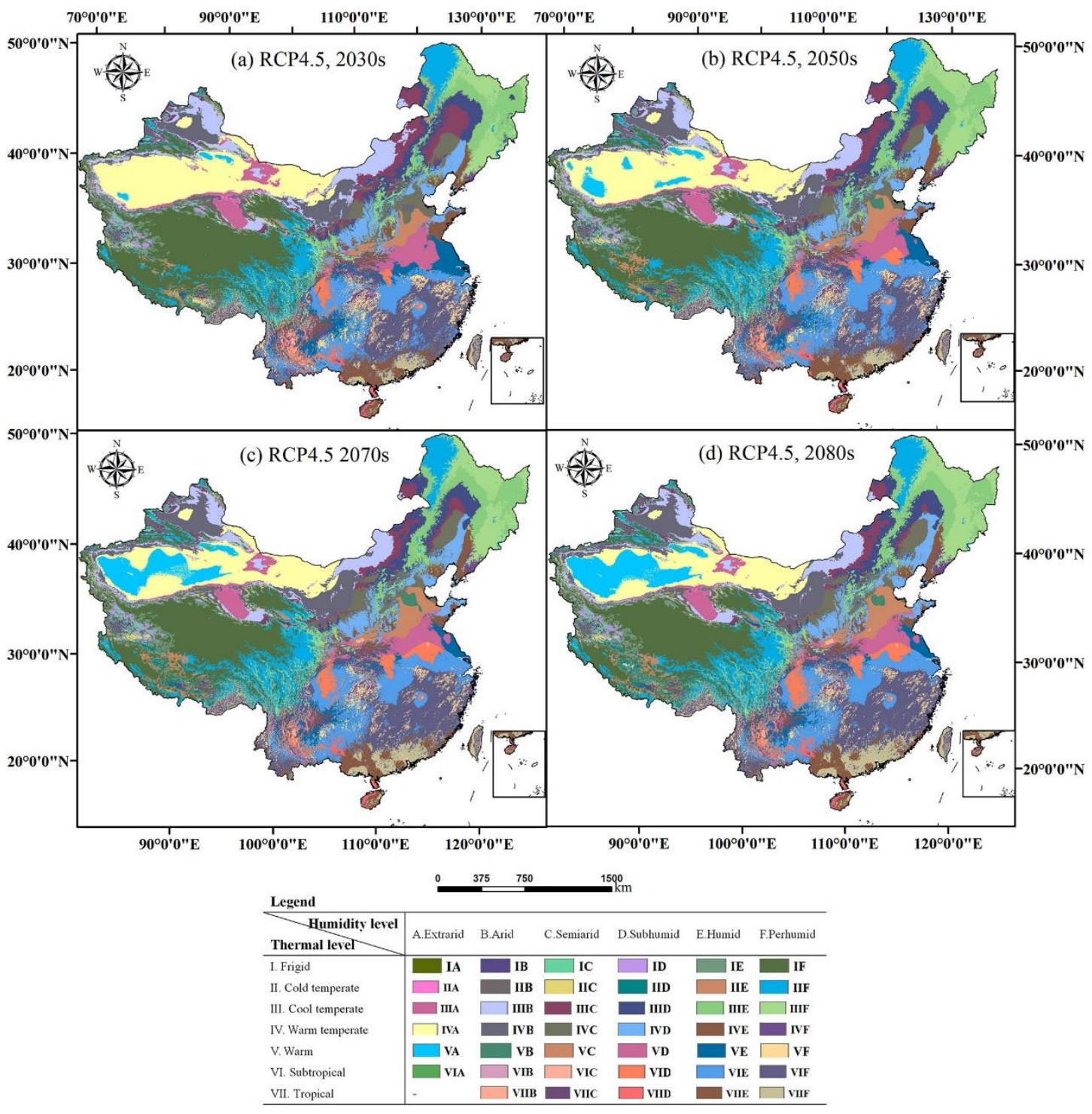

Figure 6. The spatial pattern of PNV in China in the (a) 2030s, (b) 2050s, (c) 2070s, and (d) 2080s of RCP4.5. The corresponding class names of class codes are shown in Table A1 in Appendix A.

Under the RCP8.5 scenario (Figure 7 and Table A2), the largest continuous decrease in area would occur in frigid-perhumid rain tundra, alpine meadow (IF), followed by cool temperate-humid forest steppe, deciduous broad-leaved forest (IIIE) by $3.44 \times 10^{4} \mathrm{~km}^{2}$ and $2.28 \times 10^{4} \mathrm{~km}^{2}$ every 10 years, respectively. By contrast, the largest and the second largest consistent expansions are expected to happen in warm temperate-arid warm temperate zone semidesert (IVB) and the warm temperate-semiarid warm temperate typical steppe (IVC) by $2.28 \times 10^{4} \mathrm{~km}^{2}$ and $1.36 \times 10^{4} \mathrm{~km}^{2}$ per decade, respectively. It is worth noting that the areas of VIIC and VIID are estimated to increase by $341.93 \%$ and $277.31 \%$ relative to T0, respectively. Based on the analysis of RCP2.6 and RCP4.5, the results indicate that VIIC and VIID would be more sensitive to climate changes than the other vegetation types.

\subsection{Geometrical Center Shift of Super-Classes for PNV in China}

To further reflect the macroscopic nature of PNV in the spatial movement, the centers of super-classes for PNV in China are simulated. Considering the error from elevation, we calculated the "GEODESIC" distance, which presented different changing trends in directions and distances under the three scenarios (Figure 8 and Table 5). 


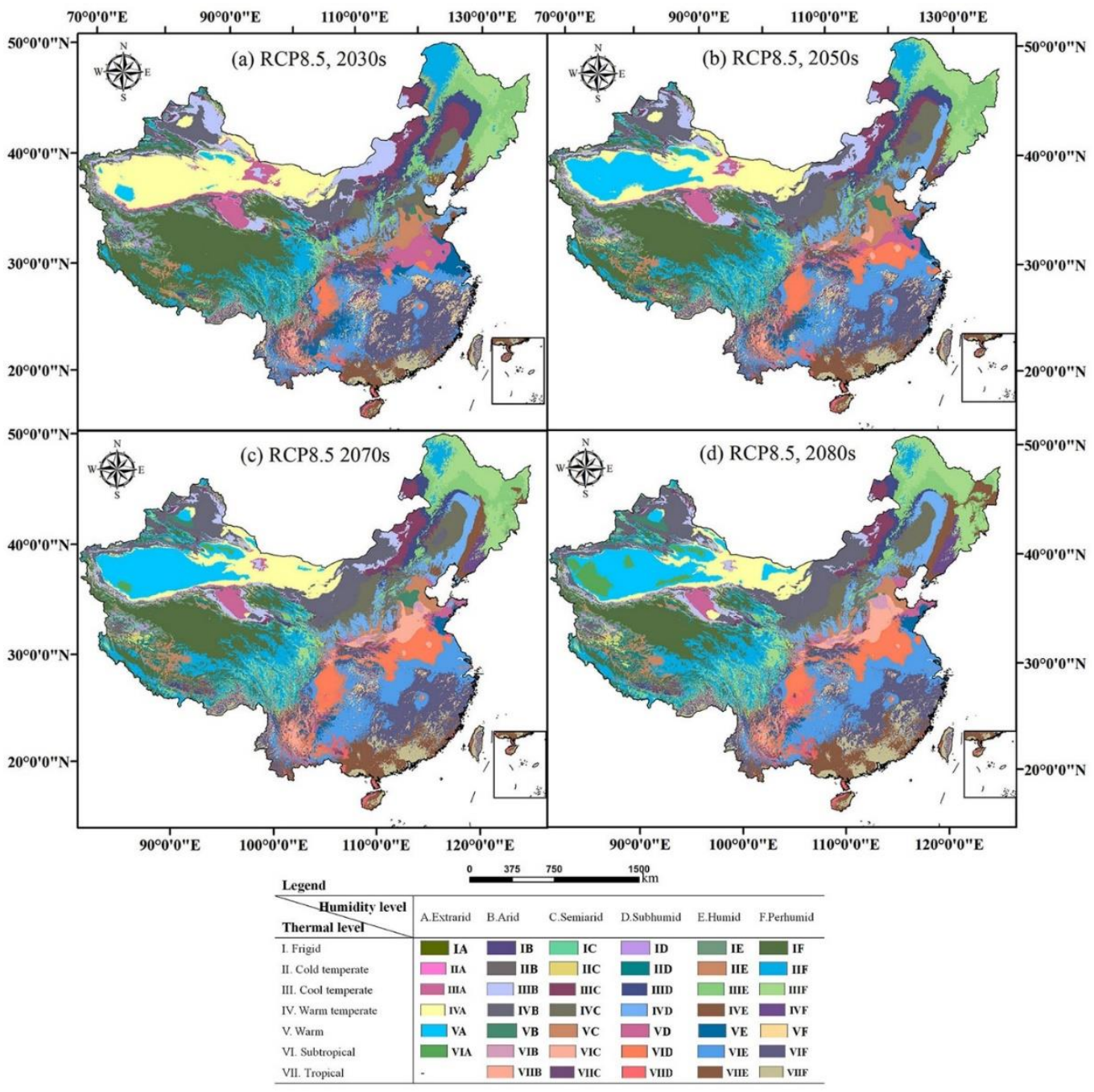

Figure 7. The spatial pattern of PNV in China in the (a) 2030s, (b) 2050s, (c) 2070s, and (d) 2080s of RCP8.5. The corresponding class names of class codes are shown in Table A1 in Appendix A.

Table 5. Geometrical center shifting distance of super-classes for PNV in China in T0 (1970-2000), T1 (2030s), T2 (2050s), T3 (2070s), and T4 (2080s) under RCP2.6, RCP4.5, and RCP8.5.

\begin{tabular}{|c|c|c|c|c|c|c|c|c|c|c|c|c|c|}
\hline \multirow{2}{*}{\multicolumn{2}{|c|}{ Super-Class Code }} & \multicolumn{4}{|c|}{ RCP2.6 (km) } & \multicolumn{4}{|c|}{ RCP4.5 (km) } & \multicolumn{4}{|c|}{ RCP8.5 (km) } \\
\hline & & \multirow{2}{*}{$\frac{\text { T0-T1 }}{56.46}$} & \multirow{2}{*}{$\frac{\text { T1-T2 }}{6.32}$} & \multirow{2}{*}{$\frac{\text { T2-T3 }}{6.57}$} & \multirow{2}{*}{$\begin{array}{c}\text { T3-T4 } \\
10.15\end{array}$} & \multirow{2}{*}{$\begin{array}{c}\text { T0-T1 } \\
64.65\end{array}$} & \multirow{2}{*}{$\begin{array}{c}\text { T1-T2 } \\
11.62\end{array}$} & \multirow{2}{*}{$\frac{\text { T2-T3 }}{8.31}$} & \multirow{2}{*}{$\begin{array}{c}\text { T3-T4 } \\
8.54\end{array}$} & \multirow{2}{*}{$\begin{array}{c}\text { T0-T1 } \\
67.14\end{array}$} & \multirow{2}{*}{$\frac{\text { T1-T2 }}{34.68}$} & \multirow{2}{*}{$\begin{array}{c}\text { T2-T3 } \\
43.21\end{array}$} & \multirow{2}{*}{$\begin{array}{c}\text { T3-T4 } \\
33.58\end{array}$} \\
\hline 1 & $\begin{array}{l}\text { Tundra and } \\
\text { alpine steppe }\end{array}$ & & & & & & & & & & & & \\
\hline 2 & Cold desert & 52.25 & 26.89 & 3.73 & 12.57 & 56.27 & 43.46 & 175.92 & 79.17 & 73.07 & 311.87 & 170.37 & 48.88 \\
\hline 3 & Semidesert & 84.97 & 79.25 & 33.08 & 7.50 & 139.58 & 55.09 & 10.18 & 7.48 & 157.83 & 63.46 & 36.93 & 97.02 \\
\hline 4 & Steppe & 786.43 & 123.43 & 152.58 & 201.30 & 859.23 & 140.45 & 55.85 & 44.20 & 863.88 & 42.80 & 140.36 & 110.38 \\
\hline 5 & $\begin{array}{l}\text { Temperate } \\
\text { humid } \\
\text { grassland }\end{array}$ & 178.35 & 80.04 & 25.41 & 401.74 & 194.27 & 213.04 & 109.35 & 85.01 & 102.37 & 432.26 & 401.46 & 190.11 \\
\hline 6 & $\begin{array}{l}\text { Temperate } \\
\text { forest }\end{array}$ & 79.35 & 26.72 & 33.30 & 42.06 & 131.18 & 34.54 & 21.70 & 13.72 & 134.97 & 90.37 & 94.97 & 41.31 \\
\hline 7 & $\begin{array}{l}\text { Subtropical } \\
\text { forest }\end{array}$ & 73.44 & 18.82 & 5.50 & 32.49 & 86.47 & 17.01 & 10.82 & 10.71 & 83.02 & 35.60 & 59.63 & 38.07 \\
\hline 8 & Tropical forest & 94.84 & 15.28 & 4.75 & 10.06 & 110.81 & 16.48 & 19.12 & 8.11 & 110.40 & 36.78 & 47.83 & 59.16 \\
\hline 9 & Warm desert & 78.88 & 535.59 & 4.15 & 10.47 & 226.56 & 334.95 & 54.16 & 5.94 & 529.66 & 57.78 & 77.48 & 78.02 \\
\hline 10 & Savanna & 181.36 & 47.27 & 11.00 & 34.38 & 195.84 & 105.61 & 131.75 & 25.04 & 144.58 & 617.05 & 406.76 & 168.96 \\
\hline
\end{tabular}



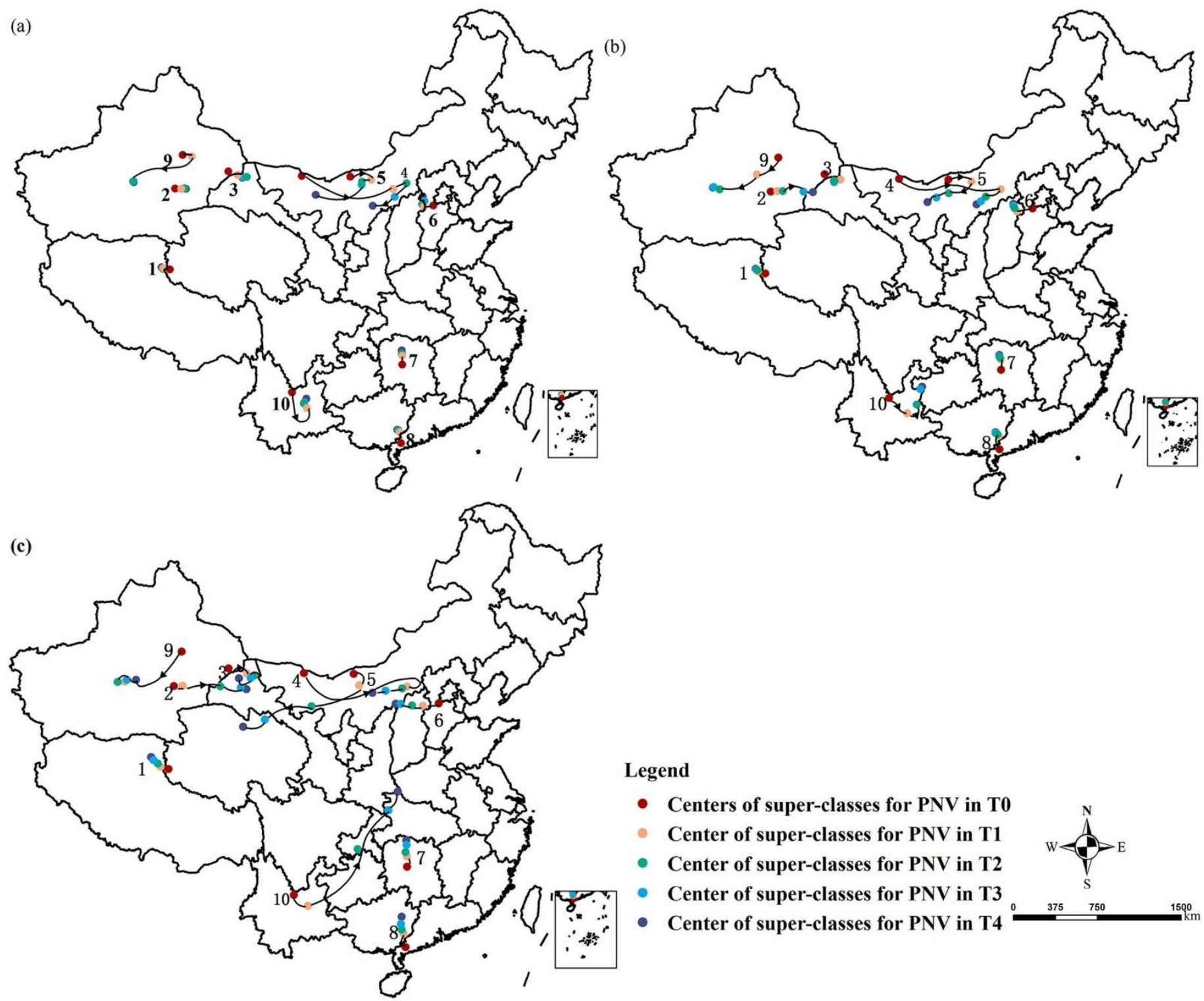

Figure 8. Geometrical center, shifting distance, and direction of super-classes for PNV of China in T0 (1970-2000), T1 (2030s), T2 (2050s), T3 (2070s), and T4 (2080s) under (a) RCP2.6, (b) RCP4.5, and (c) RCP8.5. The corresponding class names of super-classes for PNV are shown in Table 2.

As for movement directions, under the RCP2.6 scenario, the gravity center of the semidesert would move toward the southeast from T0 to T4. This super-class would continuously expand toward the southeast; in particular, its increasing rate of area would accelerate in T0-T1 then slow down after T1. Additionally, tropical forest is estimated to significantly shift toward the north, with the distribution persistently expanding to the north. Among the shrunken super-classes for PNV, the movement trend towards the west would occur in tundra and alpine steppe, which is projected to gradually shrink toward the west. By contrast, warm desert is expected to move eastward, and its area would continuously decrease eastward.

Under the RCP4.5 scenario, both subtropical forest and tropical forest would move to the north, and their distributions are predicted to continuously expand toward the north. Meanwhile, both semidesert and warm desert would significantly shift to the south. Semidesert is estimated to move to the southeast from T0-T1 then southwest from T1-T4, and its distribution would expand from southeast to southwest successively. By contrast, warm desert presents a southwest trend, which would also persistently increase toward the southwest. 
Under the RCP8.5 scenario, a movement trend towards the north is projected for tropical forest, and the super-class for PNV would continuously expand toward the north. Tropical desert grassland would move to the southwest, and is estimated to increase gradually toward the southwest. Specifically, savanna would be observed to move southeast from $\mathrm{T} 0$ to $\mathrm{T} 1$, then northeast from $\mathrm{T} 1$ to $\mathrm{T} 4$, and would expand southeast and northeast successively.

From the movement distances of each super-class from the PNV perspective, the largest movement distance of steppe in each period would occur in RCP2.6, followed by RCP4.5, reaching $1023.02 \mathrm{~km}$ and $733.52 \mathrm{~km}$, respectively, whereas tundra and alpine steppe would move the least, only $79.5 \mathrm{~km}$ and $93.12 \mathrm{~km}$, respectively. By contrast, the largest movement distance of savanna in each period is expected to happen in RCP8.5, reaching $1534.52 \mathrm{~km}$, whereas the shortest movement distance is projected for temperate forest, at only $472.23 \mathrm{~km}$.

In terms of the movement distance of each period, in RCP2.6, the longest movement distance from T1 to T2 would be observed in tropical desert at $269.42 \mathrm{~km}$, whereas steppe would move the most in all the other periods, by $545.71 \mathrm{~km}, 152.58 \mathrm{~km}$, and $201.3 \mathrm{~km}$, respectively. By contrast, the shortest movement distances during all the periods are projected for warm desert, tundra and alpine steppe, cold desert, and semidesert, at only $52.25 \mathrm{~km}, 6.32 \mathrm{~km}, 3.73 \mathrm{~km}$, and $7.5 \mathrm{~km}$, respectively.

In RCP4.5, the longest and shortest shifting distances from $\mathrm{T} 0$ to $\mathrm{T} 1$ are projected for steppe and tundra and alpine steppe, at 493.02 and $493.02 \mathrm{~km}$, respectively. Warm desert and tundra and alpine steppe from T1 to T2 would present the longest and shortest movement distances, at $256.58 \mathrm{~km}$ and $11.62 \mathrm{~km}$, respectively. In the T2-T3 period, cold desert and tundra and alpine steppe are estimated to move the longest and the smallest distances, with moving distances of $175.92 \mathrm{~km}$ and $8.31 \mathrm{~km}$, respectively. During the period of T3-T4, temperate humid grassland would have the longest moving distance, reaching $85.01 \mathrm{~km}$, whereas warm desert would move the least, at only $5.94 \mathrm{~km}$.

In RCP8.5, in the T0-T1 and T3-T4 periods, steppe and temperate humid grassland would present the largest and the smallest movement trends, at $496.96 \mathrm{~km}$ and $190.11 \mathrm{~km}$, respectively, whereas the center of tundra and alpine steppe is projected to move the least during the corresponding period, with a movement distance of $67.14 \mathrm{~km}$ and $33.58 \mathrm{~km}$, respectively. In the T1-T2 and T2-T3 periods, the longest movement distance would occur in savanna, reaching $814.22 \mathrm{~km}$ and $406.76 \mathrm{~km}$, respectively, whereas the shifting distance of temperate forest and semidesert would be the smallest during the corresponding period, at only $200.98 \mathrm{~km}$ and $36.93 \mathrm{~km}$, respectively.

\subsection{Spatio-Temporal Pattern Evolution of Super-Classes for PNV in China}

The spatio-temporal pattern evolution of super-classes for PNV across China in T4 relative to T0 is simulated under the RCP2.6, RCP4.5, and RCP8.5 scenarios (Figure 9). From each super-class from the PNV perspective, temperate forest would evolve the most across all scenarios, with areas of $45.05 \times 10^{4} \mathrm{~km}^{2}, 96.38 \times 10^{4} \mathrm{~km}^{2}$, and $120.30 \times 10^{4} \mathrm{~km}^{2}$, respectively (Table $\mathrm{A} 3$ ), indicating that temperate forest would be more sensitive to climate changes than the other vegetation types. By contrast, the smallest evolution of the areas of both warm desert and savanna would occur in RCP4.5 and RCP8.5, and the absence of any succession is expected to happen in RCP2.6. Based on the results, these two super-classes for PNV are projected to not include climate-sensitive and climate-vulnerable vegetation.

In addition, the total succession areas of super-classes for PNV in China are estimated across three scenarios. The largest succession of $441.80 \times 10^{4} \mathrm{~km}^{2}$ would occur in RCP8.5, followed by RCP4.5, of $249.23 \times 10^{4} \mathrm{~km}^{2}$, whereas the smallest succession of $148.75 \times 10^{4} \mathrm{~km}^{2}$ would be observed in RCP2.6, covering nearly $46.04 \%, 30.66 \%$, and $15.50 \%$ of the total national area. The outcomes indicate that more intense climate changes would result in a more extensive response of terrestrial vegetation. 


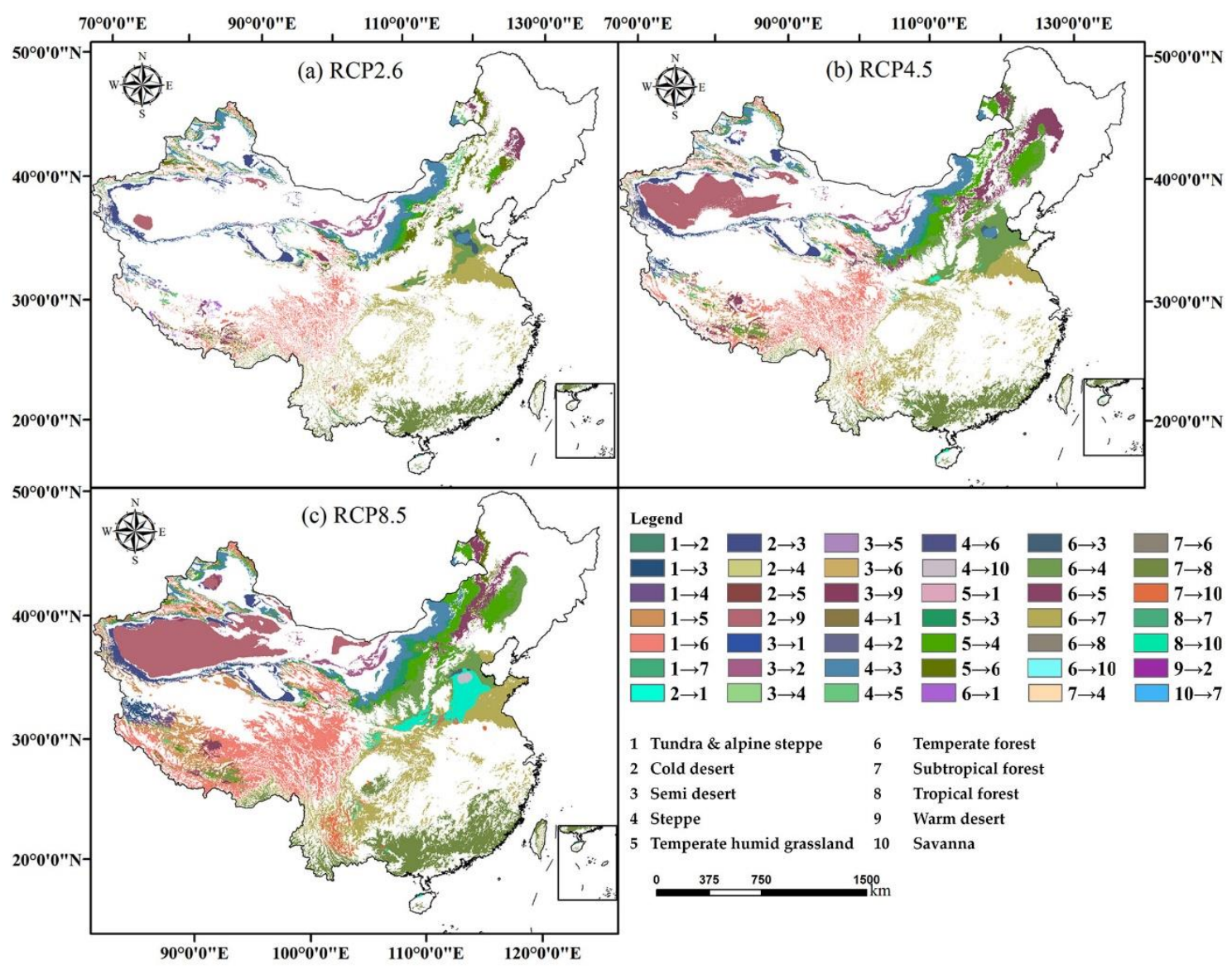

Figure 9. Spatio-temporal pattern evolution of super-classes for PNV of China in the 2080s relative to 1970-2000 under (a) RCP2.6, (b) RCP4.5, and (c) RCP8.5. The corresponding codes of super-classes for PNV are shown in Table 2.

As for evolution types, super-classes for PNV would present different evolution trends under the three scenarios. Under RCP 2.6, the largest area, of $34.36 \times 10^{4} \mathrm{~km}^{2}$, of temperate forest would convert into subtropical forest, which amounts to $3.58 \%$ of the total national area, and is evaluated to be concentrated in the North China Plain, the middle and lower reaches of the Yangtze River Plain, the northern part of the Lingnan Mountains, the YunnanGuizhou Plateau, the southern foot of the Qinghai-Tibet Plateau, the Sichuan Basin, and the Loess Plateau. Under RCP4.5, cold desert is projected to evolve into warm desert in an area of $38.87 \times 10^{4} \mathrm{~km}^{2}$, accounting for $4.05 \%$ of the total national area, which would contribute the most succession among all ecosystems. The ecosystem would be mainly distributed in the Tarim Basin and Tianshan Mountains. Under RCP8.5, tundra and alpine steppe succession is observed to be highest in temperate forest, of $69.23 \times 10^{4} \mathrm{~km}^{2}$, accounting for $7.21 \%$ of the total land area of China, which would be distributed extensively in the Qinghai-Tibet Plateau, Hengduan Mountains, Kunlun Mountains, Himalayas, and Qilian Mountains.

\subsection{Analysis of Sensitivity of PNV in China to Climate Changes}

The concept of ecosystem sensitivity mainly refers to the possible extent of terrestrial ecosystems in response to impacts associated with future climate changes. Global and regional climate changes as a consequence of anthropogenic emissions and projections of the possible extent of the effects on terrestrial ecosystems of China are essential for CSCS ecosystems in China to adapt to climate changes. The climate-sensitive and climatevulnerable regions are prone to generating ecological environment problems, which are the focus of ecological environment protection and restoration $[44,59,60]$. Therefore, the sensitivity of PNV in China is explored to serve as guidance in ecological protection and 
restoration work. The five sensitivity levels, non-sensitive area (0 changes), low-sensitivity area (one change), medium-sensitivity area (two changes), high-sensitivity area (three changes), and extreme sensitivity area (four changes), are proposed through comparing the change numbers for each grid of PNV maps in China from T0 to T4 based on previous work in the sensitivity analysis of PNV in China [3,11].

Generally, all the three RCPs agreed that the five sensitivity levels present an interphase distribution (Figure 10). The results of merging the low-sensitivity, middle-sensitivity, high-sensitivity, and extreme sensitivity regions into sensitive regions suggest that sensitive regions are concentrated, whereas the non-sensitive regions are relatively dispersed, which is consistent with the outcomes of Che et al. [3].

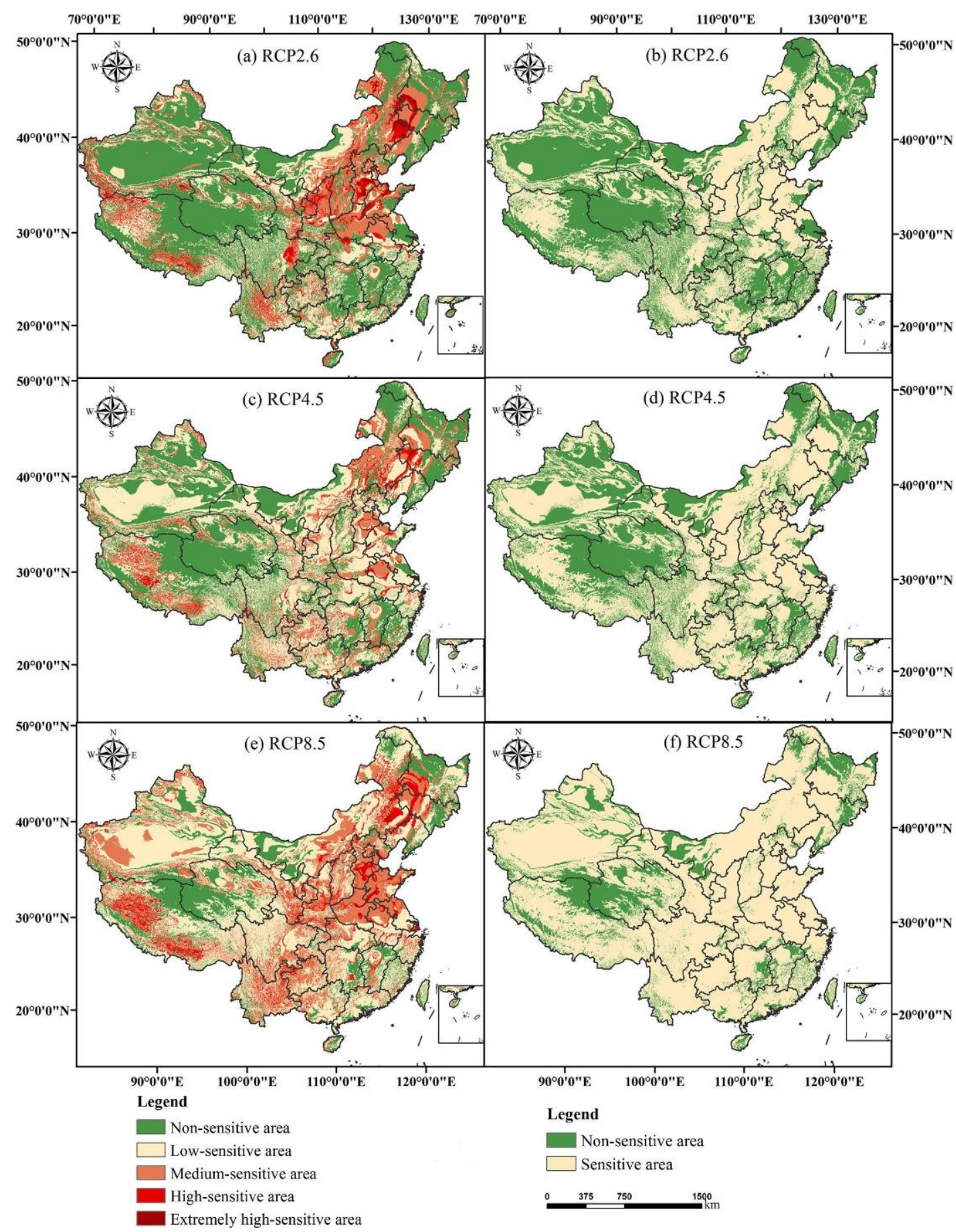

Figure 10. Spatial distribution of the five sensitivity levels of PNV in China under future climate changes based on (a) RCP2.6, (c) RCP4.5, and (e) RCP8.5. Spatial distribution of sensitive and non-sensitive areas of PNV in China under future climate changes under (b) RCP2.6, (d) RCP4.5, and (f) RCP8.5. 
Under RCP2.6, the extremely sensitive region has the smallest distribution of 15.81 $\times 10^{4} \mathrm{~km}^{2}$, covering $1.65 \%$ of the total land area of China (Figure 11a and Table 6), and is projected to only be distributed in the Northeast Plain, North China Plain, and Inner Mongolia Plateau. By contrast, the most widely distributed area is the low-sensitivity zone, at $242.42 \times 10^{4} \mathrm{~km}^{2}$, accounting for $25.26 \%$ of the total national area, which would be distributed across the Yinshan Mountains, Loess Plateau, Junggar Basin, Tarim Basin, Kunlun Mountains, Qinghai-Tibet Plateau, Hengduan Mountains, and Yunnan-Guizhou Plateau. The corresponding sensitivity of PNV in China to climate changes presents the regional differences, which are mainly caused by the joint action of climate changes and regional topography. It is noteworthy that the total area of the sensitive areas would be $496.53 \times 10^{4} \mathrm{~km}^{2}$, covering $51.74 \%$ of the total national area, whereas the non-sensitive areas, at $463.09 \times 10^{4} \mathrm{~km}^{2}$, account for $48.26 \%$ of the total national area (Figure 11a,d, and Table 6).

(a) RCP2.6

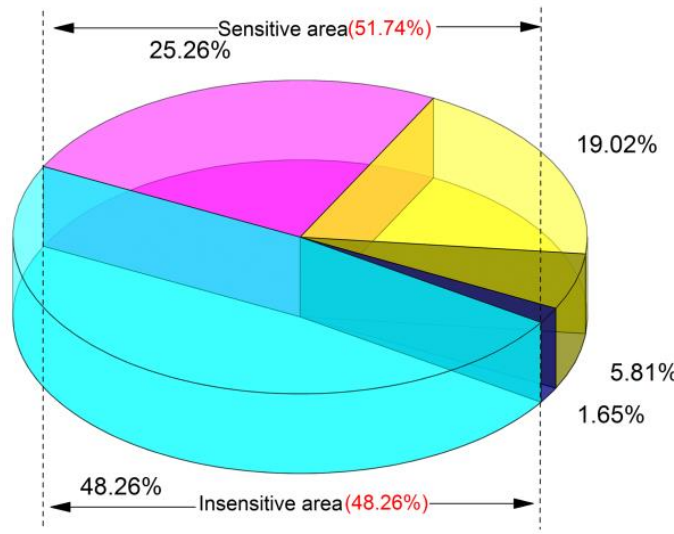

(c) RCP8.5

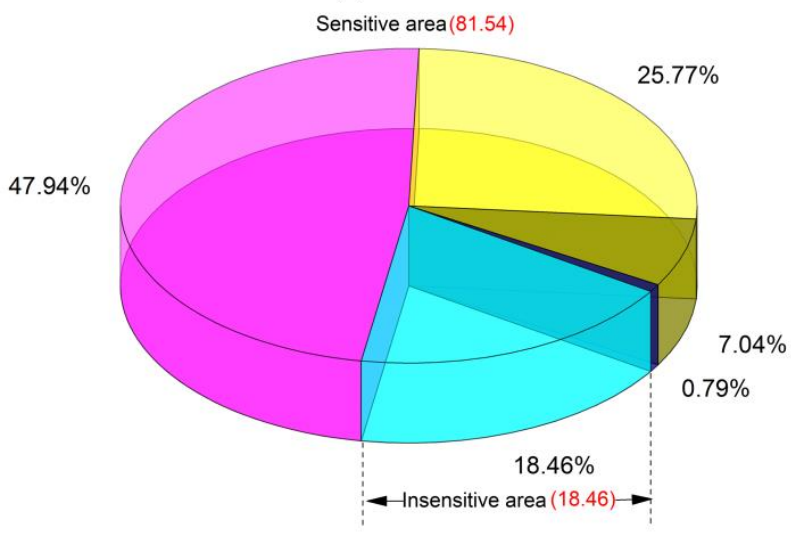

(b) RCP4.5



Insensitive area

Low sensitive area

Medium sensitive area

High sensitive area

Extremely high sensitive area

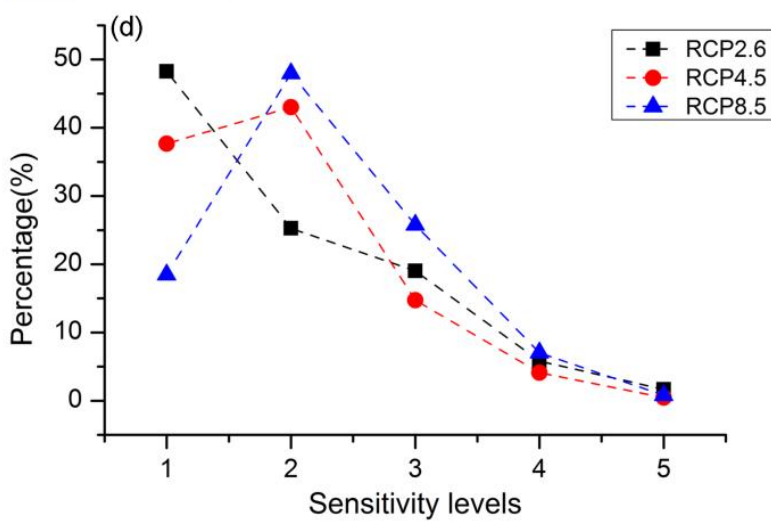

Figure 11. 3D color pie charts for percentages of each sensitivity level in (a) RCP2.6, (b) RCP4.5, and (c) RCP8.5, and (d) comparison of percentages of sensitivity levels under three scenarios. Note: 1: Insensitive area; 2: Low-sensitivity area; 3: Medium-sensitivity area; 4: High-sensitivity area; 5: Extremely high-sensitivity area. 
Table 6. Area and percentage of area with different sensitivity levels in China under RCP2.6, RCP4.5, and RCP8.5 scenarios.

\begin{tabular}{|c|c|c|c|c|c|c|c|}
\hline \multirow{2}{*}{\multicolumn{2}{|c|}{ Sensitivity }} & \multicolumn{2}{|c|}{ RCP2.6 } & \multicolumn{2}{|c|}{ RCP4.5 } & \multicolumn{2}{|c|}{ RCP8.5 } \\
\hline & & \multirow{2}{*}{$\begin{array}{c}\begin{array}{c}\text { Area }(\mathbf{1 0} \\
\left.\mathbf{k m}^{\mathbf{2}}\right)\end{array} \\
463.09\end{array}$} & \multirow{2}{*}{$\begin{array}{c}\begin{array}{c}\text { Percentage } \\
\text { (\%) }\end{array} \\
48.26\end{array}$} & \multirow{2}{*}{$\begin{array}{c}\begin{array}{c}\text { Area }\left(\mathbf{1 0}^{\mathbf{4}}\right. \\
\left.\mathbf{k m}^{\mathbf{2}}\right)\end{array} \\
361.51\end{array}$} & \multirow{2}{*}{$\begin{array}{c}\begin{array}{c}\text { Percentage } \\
(\mathbf{\%})\end{array} \\
37.67 \\
\end{array}$} & \multirow{2}{*}{$\begin{array}{c}\begin{array}{c}\text { Area }\left(\mathbf{1 0}^{\mathbf{4}}\right. \\
\left.\mathbf{k m}^{\mathbf{2}}\right)\end{array} \\
177.14\end{array}$} & \multirow{2}{*}{$\begin{array}{c}\begin{array}{c}\text { Percentage } \\
(\%)\end{array} \\
18.46\end{array}$} \\
\hline Insensitive area & Insensitive area & & & & & & \\
\hline & Low-sensitivity area & 242.41 & 25.26 & 412.70 & 43.01 & 460.00 & 47.94 \\
\hline \multirow[t]{4}{*}{ Sensitive area } & $\begin{array}{c}\text { Medium-sensitivity } \\
\text { area }\end{array}$ & 182.56 & 19.02 & 141.38 & 14.73 & 247.31 & 25.77 \\
\hline & High-sensitivity area & 55.75 & 5.81 & 39.54 & 4.12 & 67.54 & 7.04 \\
\hline & $\begin{array}{c}\text { Extremely } \\
\text { high-sensitivity area }\end{array}$ & 15.81 & 1.65 & 4.49 & 0.47 & 7.63 & 0.79 \\
\hline & Sensitive area & 496.53 & 51.74 & 598.10 & 62.33 & 782.48 & 81.54 \\
\hline
\end{tabular}

Under RCP4.5, the smallest sensitive area of $4.49 \times 10^{4} \mathrm{~km}^{2}$, covering $0.47 \%$ of the total land area in China (Figure $11 \mathrm{~b}$ and Table 6), would occur in the extremely sensitive zones, which are expected to be distributed in the Northeast Plain, North China Plain, and southern Inner Mongolia. By contrast, a low-sensitivity area of $412.70 \times 10^{4} \mathrm{~km}^{2}$, amounting to $43.01 \%$ of the total national area, would be distributed the most extensively. The zone would be observed in the Tarim Basin, the Northeast Plain, the North China Plain and the Sichuan Basin, Qilian Mountains, Kunlun Mountains and Tianshan Mountains, Quasi Algor basin, the Yunnan-Guizhou Plateau, Taiwan Mountains, and the hilly mountainous area in southern China. In addition, the total area of the sensitive areas is estimated to be $598.10 \times 10^{4} \mathrm{~km}^{2}$, covering $62.33 \%$ of the total national area, whereas the non-sensitive areas would be $361.51 \times 10^{4} \mathrm{~km}^{2}$, amounting to $37.67 \%$ of the total land area of China. The total area of the sensitive area simulated in our study is similar to that in Che et al. [3], who assessed the sensitive area in China to be $64.10 \%$ of the total national area. It is worth noting that the total sensitive area would increase by $20.46 \%$, whereas the non-sensitive areas are predicted to decrease by $21.94 \%$ under RCP4.5 relative to RCP2.6 (Figures 10 and 11d, and Table 6).

Under RCP8.5, extremely sensitive zones, with the smallest distribution area of $7.63 \times 10^{4} \mathrm{~km}^{2}$, accounting for $0.79 \%$ of the total land area of China (Figure $11 \mathrm{c}, \mathrm{d}$, and Table 6), are projected to be distributed in the Northeast Plain and North China Plain. In contrast, the most widely distributed areas would occur in the low-sensitivity zone, at $460.00 \times 10^{4} \mathrm{~km}^{2}$, covering $47.94 \%$ of the total area of China. In addition, the total area of the sensitive areas would be $782.48 \times 10^{4} \mathrm{~km}^{2}$, covering $81.54 \%$ of the total area of China, and the non-sensitive area would be $177.14 \times 10^{4} \mathrm{~km}^{2}$, accounting for $18.46 \%$ of China. Moreover, the total areas of the sensitive area and the non-sensitive area under RCP 8.5 are projected to increase by $57.59 \%$ and decrease by $61.75 \%$, respectively, relative to RCP2.6 (Figure 11d and Table 6). Based on the above analyses, it is with high confidence that a higher sensitivity of the terrestrial ecosystem would occur as a consequence of more intense climate changes.

In this paper, the modeled sensitivity results showed consistency with the distribution of China's ecologically vulnerable areas described by Du et al. [11]. The common basic characteristics of ecologically fragile areas are that the ecosystems have weak resistance to disturbance and readaptation to new habitats, a strong spatio-temporal volatility, significant edge effects, high environmental heterogeneity, and sensitivity to global climate changes. In ecologically fragile areas, both environmental and biological factors are in a critical state of phase transition, and the ecosystems are sensitive to climate changes.

\section{Conclusions}

Climate changes featuring consistently increasing air temperatures and altered rainfall patterns since the 1980s have become a consensus in the context of global climate changes. This study concludes that future climate impacts on terrestrial vegetation in China could occur by the end of the 21st century, and the extents of terrestrial ecosystems in response to future climate changes would vary greatly among different ecosystems. 
The types of PNV in China are projected to increase from 36 (1970-2000) to 39 (2030s, 2050s in RCP2.6, and 2030s in RCP4.5) and 40 (others). The CSCS model can successfully simulate vegetation distribution at a national scale. Frigid-perhumid rain tundra, alpine meadow (IF) is the most widely distributed vegetation type by the 2080s across the three RCP scenarios, whereas there are no climate conditions suitable for tropical-extra-arid tropical desert (VIIA) in China. The simulations of the dynamics of terrestrial ecosystems indicate that warm temperate-arid warm temperate zone semidesert (IVB) would benefit from the warmer and wetter climate, with a continuous expansion by the 2080s across the three RCP scenarios at the alongside a consistent contraction of cold temperate-extraarid montane desert (IIA) and cool temperate-extra-arid temperate zone desert (IIIA). As a consequence of a warming climate, tropical-semiarid savanna (VIIC) and tropicalsubhumid tropical xerophytic forest (VIID) would respond to climate changes with rapid increases of an average of $183 \%$ and $134 \%$ in the 2080s relative to $1970-2000$, respectively. Meanwhile, warm temperate-arid warm temperate zone semidesert (IVB) is expected to continuously increase the most in response to changes in future climate under the RCP2.6 and RCP8.5 scenarios, whereas under RCP4.5, the largest continuous expansion would occur in warm-extra-arid subtropical desert (VA). Among the three scenarios, RCP8.5 shows the highest change rate of PNV in China. A continuous expansion and northward shift in tropical forest would occur across all the three scenarios, whereas cold desert would suffer a consistent contraction by the 2080s. The largest and smallest shifts are projected for steppe and tundra and alpine steppe, respectively, under RCP2.6 and RCP4.5, whereas the largest and smallest movements would occur in savanna and temperate forest, respectively. In addition, the largest shift in distance is expected to happen in RCP8.5 and the shortest distance would occur in RCP2.6. Five sensitivity levels present an interphase distribution, and more intense climate changes would result in a higher sensitivity of the CSCS ecosystem in China.

All the evolution assessments of the CSCS ecosystems agree that future climate changes would benefit the succession and growth of some vegetation to a certain extent, and the most succession would occur in the higher emission scenario. However, some ecosystems in China would suffer inevitable changes. Although the greatest contribution to succession could be different under the three scenarios, the CSCS ecosystems would present an overall change trend from cold and arid to warm and wet. In general, this paper contributes to improving our understanding of the CSCS ecosystem processes in China to mitigate and effectively adapt to the impacts of future climate changes.

In future studies, it should be possible to further study the advantages and disadvantages of the CSCS model through detailed comparisons between the Holdridge life zone (HLZ) model and the dynamic global vegetation models (DGVMs), etc., and put forward optimization methods (e.g., modification of parameters).

Author Contributions: Conceptualization, S.L.; methodology, S.L.; validation, S.L.; formal analysis, S.L., J.Z., and S.Z.; investigation, S.L.; resources, S.L., J.Z., S.Z., and D.C.; data curation, S.L., S.Z., and D.C.; writing-original draft preparation, S.L.; writing—review and editing, S.L., J.Z., S.Z., Y.B., and D.C.; visualization, S.L., J.Z., Z.S., Q.L., T.C., and T.P.P.S.; supervision, J.Z. and S.Z. All authors have read and agreed to the published version of the manuscript.

Funding: This research was funded in part by the CAS Strategic Priority Research Program (No. XDA19030402), in part by the Key Basic Research Project of the Shandong Natural Science Foundation of China (No. ZR2017ZB0422), in part by the National Natural Science Foundation of China (Nos. 41871253 and 42071425), and in part by the Taishan Scholar Project of Shandong Province (No. ZR2017ZB0422).

Acknowledgments: The authors appreciate the anonymous reviewers and the editors for their valuable comments for significantly improving this manuscript. We also thank the WorldClim database and the Climate Change, Agriculture and Food Security program for providing climatic data, the National Natural Resources Standard Geographic Service Network for providing the Chinese administrative division map, and the Resource and Environment Science and Data Center for providing the vegetation map of China at a scale of 1:1,000,000. 
Conflicts of Interest: The authors declare no conflict of interest.

\section{Appendix A}

Table A1. The PNV in the CSCS model, HLZ model, and vegetation map of China at a scale of 1:1,000,000.

\begin{tabular}{|c|c|c|c|c|}
\hline \multicolumn{2}{|c|}{ Classification System } & \multicolumn{3}{|c|}{ Class Name and Code } \\
\hline \multirow{21}{*}{ CSCS } & IA & $\begin{array}{l}\text { Frigid-extra-arid frigid desert, } \\
\text { alpine desert }\end{array}$ & ID & $\begin{array}{l}\text { Frigid subhumid moist tundra, } \\
\text { alpine meadow steppe }\end{array}$ \\
\hline & IIA & $\begin{array}{l}\text { Cold temperate-extra-arid } \\
\text { montane desert }\end{array}$ & IID & $\begin{array}{l}\text { Cold temperate subhumid } \\
\text { montane meadow steppe }\end{array}$ \\
\hline & IIIA & $\begin{array}{l}\text { Cool temperate-extra-arid } \\
\text { temperate zone desert }\end{array}$ & IIID & $\begin{array}{l}\text { Cool temperate-subhumid } \\
\text { meadow steppe }\end{array}$ \\
\hline & IVA & $\begin{array}{l}\text { Warm temperate-extra arid warm } \\
\text { temperate zone desert }\end{array}$ & IVD & $\begin{array}{c}\text { Warm temperate subhumid forest } \\
\text { steppe }\end{array}$ \\
\hline & VA & $\begin{array}{c}\text { Warm-extra-arid subtropical } \\
\text { desert }\end{array}$ & VD & $\begin{array}{c}\text { Warm-subhumid deciduous } \\
\text { broad-leaved forest }\end{array}$ \\
\hline & VIA & $\begin{array}{c}\text { Subtropical-extra-arid subtropical } \\
\text { desert }\end{array}$ & VID & $\begin{array}{l}\text { Subtropical-subhumid } \\
\text { sclerophyllous forest }\end{array}$ \\
\hline & VIIA & Tropical-extra-arid tropical desert & VIID & $\begin{array}{l}\text { Tropical-subhumid tropical } \\
\text { xerophytic forest }\end{array}$ \\
\hline & IB & $\begin{array}{c}\text { Frigid-arid frigid zone semidesert, } \\
\text { alpine semidesert }\end{array}$ & IE & $\begin{array}{l}\text { Frigid-humid tundra, alpine } \\
\text { meadow }\end{array}$ \\
\hline & IIB & $\begin{array}{l}\text { Cold temperate-arid montane } \\
\text { semidesert }\end{array}$ & IIE & $\begin{array}{l}\text { Cold temperate-humid montane } \\
\text { meadow }\end{array}$ \\
\hline & IIIB & $\begin{array}{l}\text { Cool temperate-arid temperate } \\
\text { zone semidesert }\end{array}$ & IIIE & $\begin{array}{l}\text { Cool temperate-humid forest } \\
\text { steppe, deciduous broad-leaved } \\
\text { forest }\end{array}$ \\
\hline & IVB & $\begin{array}{l}\text { Warm temperate-arid warm } \\
\text { temperate zone semidesert }\end{array}$ & IVE & $\begin{array}{l}\text { Warm temperate-humid } \\
\text { deciduous broad-leaved forest }\end{array}$ \\
\hline & VB & $\begin{array}{c}\text { Warm-arid warm subtropical } \\
\text { semidesert }\end{array}$ & VE & $\begin{array}{c}\text { Warm-humid evergreen } \\
\text { broad-leaved forest }\end{array}$ \\
\hline & IB & $\begin{array}{c}\text { Frigid-arid frigid zone semidesert, } \\
\text { alpine semidesert }\end{array}$ & VIE & $\begin{array}{l}\text { Subtropical-humid evergreen } \\
\text { broad-leaved forest }\end{array}$ \\
\hline & IIB & $\begin{array}{l}\text { Cold temperate-arid montane } \\
\text { semidesert }\end{array}$ & VIIE & $\begin{array}{l}\text { Tropical-humid seasonal } \\
\text { rainforest }\end{array}$ \\
\hline & IC & $\begin{array}{l}\text { Frigid-semiarid dry tundra, alpine } \\
\text { steppe }\end{array}$ & IF & $\begin{array}{l}\text { Frigid-perhumid rain tundra, } \\
\text { alpine meadow }\end{array}$ \\
\hline & IIC & $\begin{array}{l}\text { Cold temperate semiarid montane } \\
\text { steppe }\end{array}$ & IIF & $\begin{array}{l}\text { Cold temperate perhumid taiga } \\
\text { forest }\end{array}$ \\
\hline & IIIC & $\begin{array}{l}\text { Cool temperate-semiarid } \\
\text { temperate typical steppe }\end{array}$ & IIIF & $\begin{array}{l}\text { Cold temperate perhumid mixed } \\
\text { coniferous broad-leaved forest }\end{array}$ \\
\hline & IVC & $\begin{array}{l}\text { Warm temperate-semiarid warm } \\
\text { temperate typical steppe }\end{array}$ & IVF & $\begin{array}{l}\text { Warm temperate perhumid } \\
\text { deciduous broad-leaved forest }\end{array}$ \\
\hline & VC & $\begin{array}{l}\text { Warm-semiarid subtropical } \\
\text { grass-fruticose steppe }\end{array}$ & VF & $\begin{array}{c}\text { Warm-humid } \\
\text { deciduous-evergreen } \\
\text { broad-leaved forest }\end{array}$ \\
\hline & VIC & $\begin{array}{l}\text { Subtropical-semiarid subtropical } \\
\text { brush steppe }\end{array}$ & VIF & $\begin{array}{l}\text { Subtropical perhumid evergreen } \\
\text { broad-leaved forest }\end{array}$ \\
\hline & VIIC & Tropical-semiarid savanna & VIIF & Tropical-humid rainforest \\
\hline
\end{tabular}


Table A1. Cont.

\begin{tabular}{|c|c|c|c|c|}
\hline \multicolumn{2}{|c|}{ Classification System } & \multicolumn{3}{|c|}{ Class Name and Code } \\
\hline \multirow{19}{*}{ HLZ } & 1 & polar desert & 20 & warm temperate dry forest \\
\hline & 2 & subpolar dry tundra & 21 & warm temperate moist forest \\
\hline & 3 & subpolar moist tundra & 22 & warm temperate wet forest \\
\hline & 4 & subpolar wet tundra & 23 & warm temperate rainforest \\
\hline & 5 & subpolar rain tundra & 24 & subtropical desert \\
\hline & 6 & boreal desert & 25 & subtropical desert scrub \\
\hline & 7 & boreal dry scrub & 26 & subtropical thorn woodland \\
\hline & 8 & boreal moist forest & 27 & subtropical dry forest \\
\hline & 9 & boreal wet forest & 28 & subtropical moist forest \\
\hline & 10 & boreal rain forest & 29 & subtropical wet forest \\
\hline & 11 & cool temperate desert & 30 & subtropical rainforest \\
\hline & 12 & cool temperate desert scrub & 31 & tropical desert \\
\hline & 13 & cool temperate steppe & 32 & tropical desert scrub \\
\hline & 14 & cool temperate moist forest & 33 & tropical thorn woodland \\
\hline & 15 & cool temperate wet forest & 34 & tropical very dry forest \\
\hline & 16 & cool temperate rain forest & 35 & tropical dry forest \\
\hline & 17 & warm temperate desert & 36 & tropical moist forest \\
\hline & 17 & warm temperate desert scrub & 37 & tropical wet forest \\
\hline & 19 & warm temperate thorn scrub & 38 & tropical rainforest \\
\hline \multirow{17}{*}{$\begin{array}{l}\text { 1:1,000,000 } \\
\text { vegetation } \\
\text { distribution } \\
\text { map }\end{array}$} & 1 & $\begin{array}{l}\text { cold temperate and temperate } \\
\text { mountain coniferous forest }\end{array}$ & 23 & $\begin{array}{l}\text { subalpine hard-leaved evergreen } \\
\text { broad-leaved thicket }\end{array}$ \\
\hline & 2 & temperate coniferous forest & 24 & $\begin{array}{l}\text { evergreen coniferous thicket in } \\
\text { subalpine mountains }\end{array}$ \\
\hline & 3 & subtropical coniferous forest & 25 & temperate dwarf semiarbor desert \\
\hline & 4 & tropical coniferous forest & 26 & temperate shrub desert \\
\hline & 5 & $\begin{array}{l}\text { subtropical and tropical montane } \\
\text { coniferous forest }\end{array}$ & 27 & temperate steppe shrub desert \\
\hline & 6 & $\begin{array}{c}\text { temperate coniferous and } \\
\text { deciduous broad-leaved mixed } \\
\text { forest }\end{array}$ & 28 & $\begin{array}{l}\text { temperate semishrub, dwarf } \\
\text { semishrub desert }\end{array}$ \\
\hline & 7 & $\begin{array}{l}\text { mixed forest of coniferous, } \\
\text { evergreen broad-leaved and } \\
\text { deciduous broad-leaved forest in } \\
\text { subtropical mountain areas } \\
\text { temperate deciduous broad-leaved }\end{array}$ & 29 & $\begin{array}{l}\text { temperate succulent halophyte } \\
\text { dwarf shrub desert }\end{array}$ \\
\hline & 8 & $\begin{array}{l}\text { forest, temperate deciduous leaflet } \\
\text { forest }\end{array}$ & 30 & temperate desert of annual herbs \\
\hline & 9 & temperate deciduous leaflet forest & 31 & $\begin{array}{c}\text { alpine cushion-like dwarf } \\
\text { semishrub desert }\end{array}$ \\
\hline & 10 & $\begin{array}{c}\text { subtropical deciduous } \\
\text { broad-leaved forest }\end{array}$ & 32 & $\begin{array}{l}\text { temperate grass and miscellaneous } \\
\text { grass meadow grassland }\end{array}$ \\
\hline & 11 & $\begin{array}{c}\text { subtropical evergreen and } \\
\text { deciduous broad-leaved mixed } \\
\text { forest }\end{array}$ & 33 & $\begin{array}{c}\text { typical grassland of temperate } \\
\text { tufted grass }\end{array}$ \\
\hline & 12 & $\begin{array}{l}\text { subtropical evergreen } \\
\text { broad-leaved forest }\end{array}$ & 34 & $\begin{array}{l}\text { temperate fascicled dwarf grass } \\
\text { and dwarf semishrub desert } \\
\text { grassland }\end{array}$ \\
\hline & 13 & $\begin{array}{l}\text { subtropical monsoon evergreen } \\
\text { broad-leaved forest }\end{array}$ & 35 & alpine grass and moss grassland \\
\hline & 14 & $\begin{array}{l}\text { subtropical hardleaf evergreen } \\
\text { broad-leaved forest and copse }\end{array}$ & 36 & temperate grass \\
\hline & 15 & monsoon rain forest & 37 & subtropical and tropical grass \\
\hline & 16 & tropical rain forest & 38 & $\begin{array}{c}\text { temperate grass and miscellaneous } \\
\text { grass meadow }\end{array}$ \\
\hline & 17 & $\begin{array}{l}\text { subtropical and tropical bamboo } \\
\text { forest and clusters }\end{array}$ & 39 & $\begin{array}{l}\text { temperate grass, liverwort, and } \\
\text { miscellaneous grass bog meadow }\end{array}$ \\
\hline
\end{tabular}


Table A1. Cont.

\begin{tabular}{|c|c|c|c|}
\hline \multirow{2}{*}{$\begin{array}{r}\text { Classification System } \\
18\end{array}$} & \multicolumn{3}{|c|}{ Class Name and Code } \\
\hline & $\begin{array}{c}\text { deciduous thicket in temperate } \\
\text { zone }\end{array}$ & 40 & $\begin{array}{l}\text { temperate grass and miscellaneous } \\
\text { grass salt meadow }\end{array}$ \\
\hline 19 & $\begin{array}{l}\text { subtropical, tropical evergreen } \\
\text { broad-leaved, deciduous } \\
\text { broad-leaved scrub (often } \\
\text { containing rare trees) }\end{array}$ & 41 & $\begin{array}{c}\text { alpine hyssop and miscellaneous } \\
\text { grass meadow }\end{array}$ \\
\hline 20 & $\begin{array}{l}\text { tropical coral limestone fleshy } \\
\text { evergreen broad-leaved thicket } \\
\text { and copse }\end{array}$ & 46 & alpine tundra \\
\hline 21 & $\begin{array}{l}\text { subtropical and tropical xerophytic } \\
\text { evergreen succulent prickly thicket }\end{array}$ & 47 & alpine cushioned vegetation \\
\hline 22 & $\begin{array}{l}\text { deciduous broad-leaf thicket in } \\
\text { subalpine mountains }\end{array}$ & 48 & alpine sparse vegetation \\
\hline
\end{tabular}

Table A2. Dynamics of each PNV area in proportion to the total land area of China in different periods of RCP2.6, RCP4.5, and RCP8.5 scenarios. T0, T1, T2, T3, and T4 are the periods of 1970-2000, 2030s, 2050s, 2070s, and 2080s, respectively; "_" means the PNV types do not exist.

\begin{tabular}{|c|c|c|c|c|c|c|c|c|c|c|c|c|c|c|c|}
\hline & \multirow{3}{*}{\multicolumn{2}{|c|}{ ID Class_Code Class_Name }} & \multicolumn{13}{|c|}{ Area Percentage $(\%)$} \\
\hline & & & \multirow{2}{*}{ T0 } & \multicolumn{3}{|c|}{ T1 } & \multicolumn{3}{|c|}{ T2 } & \multicolumn{3}{|c|}{ T3 } & \multicolumn{3}{|c|}{$\mathrm{T} 4$} \\
\hline & & & & RCP2.6 & $\mathrm{RCP} 4.5$ & RCP8.5 & RCP2.6 & RCP4.5 & RCP8.5 & RCP2.6 & RCP4.5 & 5 RC8.5 & RCP2.6 & RCP4.5 & RCP8.5 \\
\hline 1 & IA & $\begin{array}{l}\text { Frigid-extra-arid frigid } \\
\text { desert, alpine desert }\end{array}$ & 0.03 & - & - & - & - & - & - & - & - & - & 0.01 & - & - \\
\hline 2 & IIA & $\begin{array}{l}\text { Cold temperate-extra-arid } \\
\text { montane desert }\end{array}$ & 0.65 & 0.21 & 0.12 & 0.13 & 0.13 & 0.08 & 0.04 & 0.11 & 0.06 & 0.01 & 0.08 & 0.05 & 0.01 \\
\hline 3 & IIIA & $\begin{array}{l}\text { Cool temperate-extra arid } \\
\text { temperate zone desert }\end{array}$ & 3.19 & 2.25 & 1.91 & 1.89 & 1.97 & 1.68 & 1.32 & 1.95 & 1.41 & 0.95 & 1.86 & 1.33 & 0.73 \\
\hline 4 & IVA & $\begin{array}{c}\text { Warm temperate-extra arid } \\
\text { warm temperate zone } \\
\text { desert }\end{array}$ & 9.39 & 10.29 & 10.43 & 10.44 & 10.38 & 9.84 & 6.60 & 10.59 & 7.69 & 5.51 & 10.42 & 6.94 & 4.78 \\
\hline 5 & VA & $\begin{array}{l}\text { Warm-extra-arid } \\
\text { subtropical desert }\end{array}$ & 0.10 & 0.16 & 0.26 & 0.54 & 0.56 & 1.07 & 4.89 & 0.43 & 3.35 & 6.26 & 0.42 & 4.11 & 5.77 \\
\hline 6 & VIA & $\begin{array}{l}\text { Subtropical-extra-arid } \\
\text { subtropical desert }\end{array}$ & - & - & - & 0.01 & - & 0.01 & 0.05 & 0.01 & 0.02 & 0.28 & - & 0.03 & 1.48 \\
\hline 7 & VIIA & $\begin{array}{c}\text { Tropical-extra-arid tropical } \\
\text { desert }\end{array}$ & - & - & - & - & - & - & - & - & - & - & - & - & - \\
\hline 8 & IB & $\begin{array}{l}\text { Frigid-arid frigid zone } \\
\text { semidesert, alpine } \\
\text { semidesert }\end{array}$ & 0.46 & 0.34 & 0.18 & 0.19 & 0.19 & 0.16 & 0.09 & 0.40 & 0.13 & 0.03 & 0.51 & 0.11 & 0.03 \\
\hline 9 & IIB & $\begin{array}{l}\text { Cold temperate-arid } \\
\text { montane semidesert }\end{array}$ & 0.66 & 1.06 & 1.10 & 1.10 & 1.08 & 1.07 & 0.93 & 1.12 & 0.95 & 0.71 & 1.08 & 0.89 & 0.64 \\
\hline 10 & IIIB & $\begin{array}{l}\text { Cool temperate-arid } \\
\text { temperate zone semidesert }\end{array}$ & 3.46 & 5.27 & 5.09 & 4.84 & 4.93 & 4.34 & 3.89 & 4.80 & 4.02 & 2.60 & 4.88 & 3.97 & 2.16 \\
\hline 11 & IVB & $\begin{array}{l}\text { Warm temperate-arid } \\
\text { warm temperate zone } \\
\text { semidesert }\end{array}$ & 1.86 & 3.02 & 3.59 & 3.76 & 3.46 & 4.16 & 5.49 & 3.64 & 4.56 & 6.88 & 3.68 & 4.80 & 7.23 \\
\hline 12 & VB & $\begin{array}{l}\text { Warm-arid warm } \\
\text { subtropical semidesert }\end{array}$ & - & 0.01 & 0.02 & 0.11 & 0.23 & 0.17 & 0.29 & 0.10 & 0.25 & 0.58 & 0.24 & 0.16 & 0.54 \\
\hline 13 & VIB & $\begin{array}{c}\text { Subtropical arid } \\
\text { subtropical desert brush }\end{array}$ & - & 0.01 & 0.01 & 0.02 & $<0.01$ & 0.01 & 0.03 & 0.01 & 0.01 & 0.21 & 0.01 & 0.01 & 0.35 \\
\hline 14 & VIIB & $\begin{array}{c}\text { Tropical arid tropical desert } \\
\text { brush }\end{array}$ & - & 0.02 & 0.03 & 0.04 & 0.03 & 0.03 & 0.04 & 0.03 & 0.02 & 0.09 & 0.02 & 0.02 & 0.08 \\
\hline 15 & IC & $\begin{array}{l}\text { Frigid-semiarid dry tundra, } \\
\text { alpine steppe }\end{array}$ & 0.86 & 0.56 & 0.40 & 0.43 & 0.44 & 0.40 & 0.23 & 0.59 & 0.32 & 0.14 & 0.19 & 0.26 & 0.10 \\
\hline 16 & IIC & $\begin{array}{l}\text { Cold temperate semiarid } \\
\text { montane steppe }\end{array}$ & 0.45 & 0.44 & 0.52 & 0.49 & 0.40 & 0.47 & 0.65 & 0.38 & 0.51 & 0.62 & 0.13 & 0.52 & 0.69 \\
\hline 17 & IIIC & $\begin{array}{l}\text { Cool temperate-semiarid } \\
\text { temperate typical steppe }\end{array}$ & 2.82 & 3.83 & 4.08 & 3.97 & 4.10 & 3.02 & 3.15 & 3.18 & 2.43 & 2.49 & 0.67 & 2.33 & 2.19 \\
\hline 18 & IVC & $\begin{array}{l}\text { Warm temperate-semiarid } \\
\text { warm temperate typical } \\
\text { steppe }\end{array}$ & 0.22 & 1.60 & 2.49 & 2.58 & 2.27 & 2.22 & 3.76 & 2.41 & 2.52 & 3.85 & 0.55 & 2.61 & 3.91 \\
\hline 19 & VC & $\begin{array}{l}\text { Warm-semiarid subtropical } \\
\text { grass-fruticose steppe }\end{array}$ & - & 0.64 & 1.01 & 1.35 & 1.28 & 1.36 & 1.93 & 1.26 & 1.56 & 1.32 & 0.59 & 1.70 & 1.11 \\
\hline 20 & VIC & $\begin{array}{l}\text { Subtropical-semiarid } \\
\text { subtropical brush steppe }\end{array}$ & 0.01 & 0.19 & 0.26 & 0.32 & 0.26 & 0.20 & 0.60 & 0.23 & 0.19 & 1.63 & 0.02 & 0.21 & 1.73 \\
\hline
\end{tabular}


Table A2. Cont.

\begin{tabular}{|c|c|c|c|c|c|c|c|c|c|c|c|c|c|c|c|}
\hline & & & \multicolumn{13}{|c|}{ Area Percentage (\%) } \\
\hline & \multicolumn{2}{|c|}{ ID Class_Code Class_Name } & \multirow{2}{*}{ T0 } & \multicolumn{3}{|c|}{ T1 } & \multicolumn{3}{|c|}{ T2 } & \multicolumn{3}{|c|}{ T3 } & \multicolumn{3}{|c|}{ T4 } \\
\hline & & & & RCP2.6 & RCP4.5 & RCP8.5 & RCP2.6 & RCP4.5 & RCP8.5 & RCP2.6 & RCP4.5 & RC8.5 & RCP2.6 & RCP4.5 & RCP8.5 \\
\hline 21 & VIIC & $\begin{array}{l}\text { Tropical-semiarid savanna } \\
\text { Frigid subhumid moist }\end{array}$ & 0.01 & 0.07 & 0.10 & 0.08 & 0.07 & 0.11 & 0.12 & 0.07 & 0.09 & 0.21 & 0.03 & 0.11 & 0.22 \\
\hline 22 & ID & $\begin{array}{l}\text { tundra, alpine meadow } \\
\text { steppe }\end{array}$ & 0.99 & 0.75 & 0.67 & 0.68 & 0.69 & 0.68 & 0.57 & 0.72 & 0.63 & 0.29 & 0.44 & 0.59 & 0.23 \\
\hline 23 & IID & $\begin{array}{l}\text { Cold temperate subhumid } \\
\text { montane meadow steppe }\end{array}$ & 0.42 & 0.69 & 0.51 & 0.60 & 0.45 & 0.59 & 0.90 & 0.52 & 0.81 & 0.92 & 0.30 & 0.92 & 1.18 \\
\hline 24 & IIID & $\begin{array}{l}\text { Cool temperate-subhumid } \\
\text { meadow steppe }\end{array}$ & 3.77 & 4.40 & 4.08 & 3.81 & 3.73 & 4.09 & 3.03 & 3.99 & 4.04 & 2.42 & 2.72 & 3.78 & 2.24 \\
\hline 25 & IVD & $\begin{array}{l}\text { Warm temperate sub } \\
\text { humid forest steppe } \\
\text { Warm-subhumid }\end{array}$ & 2.03 & 2.88 & 2.93 & 3.00 & 2.62 & 2.97 & 3.43 & 2.67 & 3.22 & 3.66 & 2.01 & 3.35 & 3.71 \\
\hline 26 & VD & $\begin{array}{l}\text { deciduous broad-leaved } \\
\text { forest }\end{array}$ & 0.06 & 2.06 & 2.07 & 2.27 & 2.31 & 1.83 & 1.47 & 1.96 & 1.71 & 1.20 & 0.91 & 1.68 & 1.16 \\
\hline 27 & VID & $\begin{array}{l}\text { Subtropical-subhumid } \\
\text { sclerophyllous forest }\end{array}$ & 0.09 & 0.64 & 1.29 & 1.63 & 1.08 & 1.71 & 3.51 & 1.23 & 2.01 & 4.37 & 0.18 & 2.20 & 4.34 \\
\hline 28 & VIID & $\begin{array}{c}\text { Tropical-subhumid tropical } \\
\text { xerophytic forest }\end{array}$ & 0.01 & 0.21 & 0.27 & 0.26 & 0.23 & 0.31 & 0.37 & 0.24 & 0.30 & 0.60 & 0.05 & 0.32 & 0.79 \\
\hline 29 & IE & $\begin{array}{l}\text { Frigid-humid tundra, } \\
\text { alpine meadow }\end{array}$ & 2.07 & 1.83 & 1.28 & 1.57 & 1.47 & 1.34 & 1.43 & 1.53 & 1.52 & 0.89 & 2.57 & 1.52 & 0.73 \\
\hline 30 & IIE & $\begin{array}{l}\text { Cold temperate-humid } \\
\text { montane meadow }\end{array}$ & 1.56 & 1.20 & 1.12 & 1.34 & 1.25 & 1.28 & 1.44 & 1.20 & 1.28 & 1.75 & 1.84 & 1.22 & 1.89 \\
\hline 31 & IIIE & $\begin{array}{l}\text { Cool temperate-humid } \\
\text { forest steppe, deciduous } \\
\text { broad-leaved forest }\end{array}$ & 9.61 & 5.90 & 5.25 & 4.95 & 5.14 & 5.41 & 4.76 & 5.00 & 5.35 & 4.04 & 8.73 & 4.83 & 3.49 \\
\hline 32 & IVE & $\begin{array}{c}\text { Warm temperate-humid } \\
\text { deciduous broad-leaved } \\
\text { forest }\end{array}$ & 5.43 & 2.72 & 2.69 & 2.62 & 2.40 & 2.55 & 2.18 & 2.37 & 2.31 & 2.30 & 5.09 & 2.26 & 3.06 \\
\hline 33 & VE & $\begin{array}{l}\text { Warm-humid evergreen } \\
\text { broad-leaved forest } \\
\text { Subtropical-humid }\end{array}$ & 4.97 & 3.23 & 2.91 & 2.55 & 2.77 & 2.40 & 1.65 & 2.34 & 1.93 & 1.18 & 4.07 & 1.98 & 1.26 \\
\hline 34 & VIE & $\begin{array}{c}\text { evergreen broad-leaved } \\
\text { forest }\end{array}$ & 2.58 & 4.29 & 4.75 & 4.52 & 4.05 & 6.23 & 5.79 & 4.25 & 5.49 & 5.75 & 5.48 & 5.37 & 6.33 \\
\hline 35 & VIIE & $\begin{array}{l}\text { Tropical-humid seasonal } \\
\text { rain forest }\end{array}$ & 0.55 & 1.37 & 1.69 & 1.61 & 1.54 & 1.92 & 2.16 & 1.69 & 1.70 & 2.68 & 1.85 & 1.59 & 2.93 \\
\hline 36 & IF & $\begin{array}{l}\text { Frigid-perhumid rain } \\
\text { tundra, alpine meadow }\end{array}$ & 15.56 & 14.37 & 14.97 & 13.91 & 14.96 & 13.38 & 11.76 & 14.25 & 12.85 & 9.69 & 13.48 & 12.66 & 8.16 \\
\hline 37 & IIF & $\begin{array}{l}\text { Cold temperate perhumid } \\
\text { taiga forest }\end{array}$ & 6.47 & 6.61 & 6.54 & 6.65 & 6.46 & 7.10 & 6.72 & 6.74 & 7.10 & 7.39 & 6.86 & 7.20 & 7.49 \\
\hline 38 & IIIF & $\begin{array}{l}\text { Cold temperate perhumid } \\
\text { mixed coniferous } \\
\text { broad-leaved forest }\end{array}$ & 5.12 & 4.66 & 4.48 & 4.92 & 4.80 & 5.60 & 5.14 & 5.62 & 5.78 & 6.76 & 5.38 & 6.32 & 7.35 \\
\hline 39 & IVF & $\begin{array}{l}\text { Warm temperate perhumid } \\
\text { deciduous broad-leaved } \\
\text { forest }\end{array}$ & 2.91 & 2.30 & 1.85 & 1.77 & 1.82 & 1.96 & 1.53 & 1.99 & 1.94 & 1.56 & 1.87 & 1.87 & 1.81 \\
\hline 40 & $\mathrm{VF}$ & $\begin{array}{c}\text { Warm-humid } \\
\text { deciduous-evergreen } \\
\text { broad-leaved forest }\end{array}$ & 4.68 & 2.76 & 2.25 & 2.02 & 2.67 & 1.86 & 1.36 & 2.49 & 1.75 & 0.81 & 2.36 & 1.55 & 0.71 \\
\hline 41 & VIF & $\begin{array}{l}\text { Subtropical perhumid } \\
\text { evergreen broad-leaved } \\
\text { forest }\end{array}$ & 6.24 & 6.10 & 5.81 & 5.87 & 6.55 & 5.36 & 5.39 & 6.69 & 6.51 & 5.63 & 7.09 & 6.72 & 5.00 \\
\hline 42 & VIIF & Tropical-humid rainforest & 0.75 & 1.08 & 1.00 & 1.11 & 1.22 & 1.08 & 1.28 & 1.20 & 1.67 & 1.74 & 1.36 & 1.93 & 2.40 \\
\hline
\end{tabular}

Table A3. Area and percentage of super-class evolution relative to T0 (1970-2000) under RCP2.6, RCP4.5, and RCP8.5 scenarios. "-" means that the succession type does not exist; the corresponding super-classes for PNV are referred to in Table 4 .

\begin{tabular}{|c|c|c|c|c|c|c|c|}
\hline \multirow[b]{2}{*}{ ID } & \multirow[b]{2}{*}{ Evolution Type } & \multicolumn{2}{|c|}{ RCP2.6 } & \multicolumn{2}{|c|}{$\mathrm{RCP} 4.5$} & \multicolumn{2}{|c|}{ RCP8.5 } \\
\hline & & $\begin{array}{c}\text { Area }\left(10^{4}\right. \\
\left.\mathbf{k m}^{2}\right)\end{array}$ & $\begin{array}{c}\text { Percentage } \\
(\%)\end{array}$ & $\begin{array}{c}\text { Area }\left(10^{4}\right. \\
\left.\mathbf{k m}^{2}\right)\end{array}$ & $\begin{array}{c}\text { Percentage } \\
(\%)\end{array}$ & $\begin{array}{c}\text { Area }\left(10^{4}\right. \\
\left.\text { km }^{2}\right)\end{array}$ & $\begin{array}{c}\text { Percentage } \\
(\%)\end{array}$ \\
\hline 0 & $1 \rightarrow 2$ & 0.02 & $<0.01$ & $<0.01$ & $<0.01$ & $<0.01$ & $<0.01$ \\
\hline 1 & $1 \rightarrow 3$ & 2.26 & 0.24 & 2.61 & 0.27 & 4.87 & 0.51 \\
\hline 2 & $1 \rightarrow 4$ & 0.26 & 0.03 & 1.99 & 0.21 & 5.31 & 0.55 \\
\hline 3 & $1 \rightarrow 5$ & 6.00 & 0.63 & 10.25 & 1.07 & 25.31 & 2.64 \\
\hline 4 & $1 \rightarrow 6$ & 21.19 & 2.21 & 32.91 & 3.43 & 69.23 & 7.21 \\
\hline 5 & $1 \rightarrow 7$ & - & - & $<0.01$ & $<0.01$ & $<0.01$ & $<0.01$ \\
\hline 6 & $2 \rightarrow 1$ & 0.02 & $<0.01$ & 0.01 & $<0.01$ & $<0.01$ & $<0.01$ \\
\hline 7 & $2 \rightarrow 3$ & 10.93 & 1.14 & 12.56 & 1.31 & 11.49 & 1.20 \\
\hline 8 & $2 \rightarrow 4$ & 0.01 & $<0.01$ & 0.12 & 0.01 & 0.09 & 0.01 \\
\hline 9 & $2 \rightarrow 5$ & 0.01 & $<0.01$ & 0.01 & $<0.01$ & 0.01 & 0.00 \\
\hline 10 & $2 \rightarrow 9$ & 3.07 & 0.32 & 38.87 & 4.05 & 67.99 & 7.09 \\
\hline
\end{tabular}


Table A3. Cont.

\begin{tabular}{|c|c|c|c|c|c|c|c|}
\hline \multirow[b]{2}{*}{ ID } & \multirow[b]{2}{*}{ Evolution Type } & \multicolumn{2}{|c|}{ RCP2.6 } & \multicolumn{2}{|c|}{ RCP4.5 } & \multicolumn{2}{|c|}{ RCP8.5 } \\
\hline & & $\begin{array}{c}\text { Area }\left(10^{4}\right. \\
\left.\mathbf{k m}^{2}\right)\end{array}$ & $\begin{array}{c}\text { Percentage } \\
(\%)\end{array}$ & $\begin{array}{c}\text { Area }\left(10^{4}\right. \\
\left.\text { km }^{2}\right)\end{array}$ & $\begin{array}{c}\text { Percentage } \\
(\%)\end{array}$ & $\begin{array}{c}\text { Area }\left(10^{4}\right. \\
\left.\mathbf{k m}^{2}\right)\end{array}$ & $\begin{array}{c}\text { Percentage } \\
(\%)\end{array}$ \\
\hline 11 & $3 \rightarrow 1$ & 0.12 & 0.01 & $<0.01$ & $<0.01$ & - & - \\
\hline 12 & $3 \rightarrow 2$ & 5.84 & 0.61 & 4.45 & 0.46 & 5.45 & 0.57 \\
\hline 13 & $3 \rightarrow 4$ & 0.33 & 0.03 & 1.02 & 0.11 & 1.03 & 0.11 \\
\hline 14 & $3 \rightarrow 5$ & 0.75 & 0.08 & 0.40 & 0.04 & 0.07 & 0.01 \\
\hline 15 & $3 \rightarrow 6$ & 0.02 & $<0.01$ & $<0.01$ & $<0.01$ & 0.00 & 0.00 \\
\hline 16 & $3 \rightarrow 9$ & - & - & 0.05 & 0.01 & 0.74 & 0.08 \\
\hline 17 & $4 \rightarrow 1$ & 0.07 & 0.01 & $<0.01$ & $<0.01$ & - & - \\
\hline 18 & $4 \rightarrow 2$ & $<0.01$ & $<0.01$ & 0.00 & $<0.01$ & $<0.01$ & $<0.01$ \\
\hline 19 & $4 \rightarrow 3$ & 25.53 & 2.66 & 24.06 & 2.51 & 26.54 & 2.77 \\
\hline 20 & $4 \rightarrow 5$ & 3.92 & 0.41 & 1.21 & 0.13 & 0.69 & 0.07 \\
\hline 21 & $4 \rightarrow 6$ & 0.27 & 0.03 & 0.06 & 0.01 & 0.03 & $<0.01$ \\
\hline 22 & $4 \rightarrow 10$ & - & - & - & - & 1.20 & 0.12 \\
\hline 23 & $5 \rightarrow 1$ & 0.53 & 0.06 & $<0.01$ & $<0.01$ & - & - \\
\hline 24 & $5 \rightarrow 3$ & 4.07 & 0.42 & 3.20 & 0.33 & 7.91 & 0.82 \\
\hline 25 & $5 \rightarrow 4$ & 6.25 & 0.65 & 27.32 & 2.85 & 32.68 & 3.41 \\
\hline 26 & $5 \rightarrow 6$ & 17.93 & 1.87 & 8.62 & 0.90 & 7.19 & 0.75 \\
\hline 27 & $6 \rightarrow 1$ & 0.95 & 0.10 & 0.03 & $<0.01$ & $<0.01$ & $<0.01$ \\
\hline 28 & $6 \rightarrow 3$ & 1.83 & 0.19 & 0.50 & 0.05 & 0.67 & 0.07 \\
\hline 29 & $6 \rightarrow 4$ & 7.87 & 0.82 & 29.63 & 3.09 & 31.77 & 3.31 \\
\hline 30 & $6 \rightarrow 5$ & 9.66 & 1.01 & 29.08 & 3.03 & 17.48 & 1.82 \\
\hline 31 & $6 \rightarrow 7$ & 34.36 & 3.58 & 36.59 & 3.81 & 55.58 & 5.79 \\
\hline 32 & $6 \rightarrow 8$ & - & - & - & - & $<0.01$ & $<0.01$ \\
\hline 33 & $6 \rightarrow 10$ & 0.05 & $<0.01$ & 0.56 & 0.06 & 14.80 & 1.54 \\
\hline 34 & $7 \rightarrow 4$ & 0.03 & $<0.01$ & 0.44 & 0.05 & $<0.01$ & $<0.01$ \\
\hline 35 & $7 \rightarrow 6$ & 0.12 & 0.01 & 0.02 & $<0.01$ & $<0.01$ & $<0.01$ \\
\hline 36 & $7 \rightarrow 8$ & 19.06 & 16.55 & 24.97 & 2.60 & 46.82 & 4.88 \\
\hline 37 & $7 \rightarrow 10$ & 0.43 & 0.04 & 2.20 & 0.23 & 6.52 & 0.68 \\
\hline 38 & $8 \rightarrow 7$ & $<0.01$ & $<0.01$ & $<0.01$ & $<0.01$ & - & - \\
\hline 39 & $8 \rightarrow 10$ & 0.13 & 0.01 & 0.46 & 0.05 & 0.32 & 0.03 \\
\hline 40 & $9 \rightarrow 2$ & 0.04 & $<0.01$ & $<0.01$ & $<0.01$ & - & - \\
\hline 41 & $10 \rightarrow 7$ & $<0.01$ & $<0.01$ & - & - & - & - \\
\hline
\end{tabular}

\section{References}

1. Liang, T.G.; Feng, Q.S.; Cao, J.J.; Xie, H.J.; Lin, H.L.; Zhao, J.; Ren, J.Z. Changes in global potential vegetation distributions from 1911 to 2000 as simulated by the Comprehensive Sequential Classification System approach. Chin. Sci. Bull. 2012, 57, 1298-1310. [CrossRef]

2. Zhao, C.Y. Potential vegetation modelling with variable leaf area index in semi-arid grassland of Loess plateau, China. IEEE Cat. 2003, 5, 3311-3313. [CrossRef]

3. Che, Y.J.; Zhao, J.; Zhang, M.J.; Wang, S.J.; Qi, Y. Potential vegetation and its sensitivity under different climate change scenarios from 2070 to 2099 in China. Acta Ecol. Sin. 2016, 36, 2885-2895. [CrossRef]

4. Fang, J.Y.; Zhu, J.L.; Shi, Y. The responses of ecosystems to global warming. Chin. Sci. Bull 2018, 63, 136-140. [CrossRef]

5. Tang, G.P.; Shafer, S.L.; Bartlein, P.J.; Holman, J.O. Effects of experimental protocol on global vegetation model accuracy: A comparison of simulated and observed vegetation patterns for Asia. Ecol. Model. 2009, 220, 1481-1491. [CrossRef]

6. Lee, E.; He, Y.Q.; Zhou, M.; Liang, J.J. Potential feedback of recent vegetation changes on summer rainfall in the Sahel. PhGeo 2015, 36, 449-470. [CrossRef]

7. Mahmood, R.; Pielke, R., Sr.; Hubbard, K.; Niyogi, D.; Dirmeyer, P.; Mcalpine, C.; Carleton, A.M.; Hale, R.; Gameda, S.; Beltrán-Przekurat, A.; et al. Land cover changes and their biogeophysical effects on climate. IJCli 2014, 34, 929-953. [CrossRef]

8. Tapiador, F.J.; Moreno, R.; Navarro, A.; Luis Sanchez, J.; Garcia-Ortega, E. Climate classifications from regional and global climate models: Performances for present climate estimates and expected changes in the future at high spatial resolution. AtmRe 2019, 228, 107-121. [CrossRef]

9. Zhang, J.H.; Fu, C.B.; Yan, X.D.; Emori, S.; Kanzawa, H. Global Respondence Analysis of LAI Versus Surface Air Temperature and Precipitation Variations. Chin. J. Geophys. 2002, 45, 631-637. [CrossRef] 
10. Zhang, J.H.; Yao, F.M.; Fu, C.B.; Yan, X.D. Study on response of ecosystem to the East Asian monsoon in eastern China using LAI data derived from remote sensing information. Prog. Nat. Sci. 2004, 14, 279-282. [CrossRef]

11. Du, H.Y.; Zhao, J.; Shi, Y.F.; Che, Y.J. The succession of potential vegetation in China and its sensitivity under climate change. Chin. J. Ecol. 2018, 37, 1459-1466. [CrossRef]

12. Gang, C.C.; Zhang, Y.Z.; Wang, Z.Q.; Chen, Y.Z.; Yue, Y.; Li, J.L.; Ji Mi, C.; Qi, J.G.; Inakwu, O. Modeling the dynamics of distribution, extent, and NPP of global terrestrial ecosystems in response to future climate change. Glob. Planet. Chang. 2017, 148, 153-165. [CrossRef]

13. Gang, C.C.; Zhou, W.; Li, J.L.; Chen, Y.Z.; Mu, S.J.; Ren, J.Z.; Chen, J.M.; Zhao, J. Assessing the Spatiotemporal Variation in Distribution, Extent and NPP of Terrestrial Ecosystems in Response to Climate Change from 1911 to 2000. PLoS ONE 2013, 8, 1-12. [CrossRef]

14. Nzabarinda, V.; Bao, A.; Xu, W.; Uwamahoro, S.; Jiang, L.; Duan, Y.; Nahayo, L.; Yu, T.; Wang, T.; Long, G. Assessment and Evaluation of the Response of Vegetation Dynamics to Climate Variability in Africa. Sustainability 2021, 13, 1234. [CrossRef]

15. Cao, D.; Zhang, J.; Xun, L.; Yang, S.; Yao, F. Spatiotemporal variations of global terrestrial vegetation climate potential productivity under climate change. Sci. Total Environ. 2021, 770, 145320. [CrossRef]

16. Horion, S.; Cornet, Y.; Erpicum, M.; Tychon, B. Studying interactions between climate variability and vegetation dynamic using a phenology based approach. Int. J. Appl. Earth Obs. 2013, 20, 20-32. [CrossRef]

17. Igbawua, T.; Zhang, J.H.; Chang, Q.; Yao, F.M. Vegetation dynamics in relation with climate over Nigeria from 1982 to 2011. Environ. Earth Sci. 2016, 75, 518-533. [CrossRef]

18. Chang, Q.; Zhang, J.H.; Jiao, W.Z.; Yao, F.M.; Wang, S.Y. Spatiotemporal dynamics of the climatic impacts on greenup date in the Tibetan Plateau. Environ. Earth Sci. 2016, 75, 1343-1356. [CrossRef]

19. Yao, F.M.; Qin, P.C.; Zhang, J.H.; Lin, E.D.; Boken, V. Uncertainties in assessing the effect of climate change on agriculture using model simulation and uncertainty processing methods. Chin. Sci. Bull. 2011, 56, 729-737. [CrossRef]

20. Chiarucci, A.; Arau'jo, M.B.; Decocq, G.; Beierkuhnlein, C.; Ferna'ndez-Palacios, J.M.A. The concept of potential natural vegetation: An epitaph? J. Veg. Sci. 2010, 21, 1172-1178. [CrossRef]

21. Li, F.; Zhao, J.; Zhao, C.Y.; Hao, J.M.; Zheng, J.J. The potential vegetation spatial distributions and patterns in China. Acta Ecol. Sin. 2008, 28, 5347-5355. [CrossRef]

22. Lin, H.L.; Feng, Q.S.; Liang, T.G.; Ren, J.Z. Modelling global-scale potential grassland changes in spatio-temporal patterns to global climate change. Int. J. Sustain. Dev. World Ecol. 2013, 20, 83-96. [CrossRef]

23. Bolliger, J.; Kienast, F.; Bugmann, H. Comparing models for tree distributions: Concept, structures, and behavior. Ecol. Model. 2000, 134, 89-102. [CrossRef]

24. Yue, T.X.; Fan, Z.M.; Chen, C.F.; Sun, X.F.; Li, B.L. Surface modelling of global terrestrial ecosystems under three climate change scenarios. Ecol. Model. 2011, 222, 2342-2361. [CrossRef]

25. Hickler, T.; Vohland, K.; Feehan, J.; Miller, P.A.; Smith, B.; Costa, L.; Giesecke, T.; Fronzek, S.; Carter, T.R.; Cramer, W.; et al Projecting the future distribution of European potential natural vegetation zones with a generalized, tree species-based dynamic vegetation model. Glob. Ecol. Biogeogr. 2015, 21, 50-63. [CrossRef]

26. Kaplan, J.O.; Bigelow, N.H.; Prentice, I.C.; Harrison, S.P.; Bartlein, P.J.; Christensen, T.R.; Cramer, W.; Matveyeva, N.V.; Mcguire, A.D.; Murray, D.F. Climate change and Arctic ecosystems: 2. Modeling, paleodata-model comparisons, and future projections. J. Geophys. Res. Atmos. 2003, 108, 12-17. [CrossRef]

27. Ni, J. BIOME Models: Main Principles and Applications. Acta Phytoecol. Sin. 2002, 26, 481-488.

28. Horidge, L.R. Determination of World Plant Formations From Simple Climatic Data. Science 1947, 105, 367. [CrossRef]

29. Cramer, W.; Bondeau, A.; Woodward, F.I.; Prentice, I.C.; Betts, R.A.; Brovkin, V.; Cox, P.M.; Fisher, V.; Foley, J.A.; Friend, A.D. Global response of terrestrial ecosystem structure and function to $\mathrm{CO}_{2}$ and climate change: Results from six dynamic global vegetation models. Glob. Chang. Biol. 2001, 21, 50-63. [CrossRef]

30. Salzmann, U.; Haywood, A.M.; Lunt, D.J.; Valdes, P.J.; Hill, D.J. A new global biome reconstruction and data-model comparison for the Middle Pliocene. Glob. Ecol. Biogeogr. 2008, 17, 432-447. [CrossRef]

31. Haxeltine, A.; Prentice, I.C. BIOME3: An equilibrium terrestrial biosphere model based on ecophysiological constraints, resource availability, and competition among plant functional types. GBioC 1996, 10, 693-709. [CrossRef]

32. Zheng, Y.; Xie, Z.; Jiang, L.; Shimizu, H.; Drake, S. Changes in Holdridge Life Zone diversity in the Xinjiang Uygur Autonomous Region (XUAR) of China over the past 40 years. J. Arid Environ. 2006, 66, 113-126. [CrossRef]

33. Ma, R.F.; Ma, X.Z. Using Holdridge life zone classification system to analyze the climate change characteristics of Inner Mongolia grassland in the past 50 years. Meteorol. J. Inn. Mong. 2008, 2, $24-28$.

34. Mulholland, P.J.; Fellows, C.; Tank, J.; Grimm, N.; Webster, J.; Hamilton, S.; Martí, E. Inter-Biome Comparison of Factors Controlling Stream Metabolism. Freshw. Biol. 2001, 46, 1503-1517. [CrossRef]

35. Hao, J.M. Study on the Holdridge Life Zone and Potential Vegetation Spatial Paterns in China; Northwest Normal University: Lanzhou, China, 2009.

36. Wang, M.; Venevsky, S.; Wu, C.; Berdnikov, S.; Sorokina, V.; Kulygin, V. Description of local carbon flux from large scale gridded climate data by a global dynamic vegetation model at variable time steps: Example of Euroflux sites. ScTEn 2020, $756,143492$.

37. Ren, J.Z.; Hu, Z.Z.; Mu, X.D.; Zhang, J.J. Comprehensive and Sequential Classification System of Grassland and its generic meaning. Chin. J. Grassl. 1980, 29, 12-24. 
38. Ren, J.Z.; Hu, Z.Z.; Zhao, J.; Zhang, D.G.; Hou, F.J.; Lin, H.l.; Mu, X.D. A grassland classification system and its application in China. Rangel. J. 2008, 30, 199-209. [CrossRef]

39. Lin, H.L.; Zhao, J.; Tian Gang, L.; Bogaer, J.; Li, Z.Q. A classification indices-based model for net primary productivity (NPP) and potential productivity of vegetation in China. Int. J. Biomath. 2012, 5, 1-23. [CrossRef]

40. Fischlin, A.; Midgley, G.F.; Price, J.T.; Leemans, R.; Gopal, B.; Turley, C.; Rounsevell, M.; Dube, O.P.; Tarazona, J.; Velichko, A.A Climate Change 2007: Impacts, Adaptation and Vulnerability. Contribution of Working Group II to the Fourth Assessment Report of the Intergovernmental Panel on Climate Change; Cambridge University Press: Cambridge, UK, 2007; pp. 211-272.

41. Cao, D.; Zhang, J.-H.; Yan, H.; Xun, L.; Yang, S.; Yun, B.; Zhang, S.; Yao, F.; Zhou, W. Regional Assessment of Climate Potential Productivity of Terrestrial Ecosystems and Its Responses to Climate Change Over China From 1980-2018. IEEE Access 2020. [CrossRef]

42. Fick, S.E.; Hijmans, R.J. WorldClim 2: New 1-km spatial resolution climate surfaces for global land areas. IJCli 2017, 37, 4302-4315. [CrossRef]

43. Xiu, L.N. Spatio-Temporal Distribution Characteristics of the CSCS-Based Potential Natural Vegetation in China; Lanzhou University: Lanzhou, China, 2014.

44. Ren, Z.C.; Zhu, H.Z.; Shi, H.; Liu, X.N. Spatio-temporal distribution pattern of potential natural vegetation and its response to climate change from Last Interglacial to future 2070s in China. J. Nat. Resour. 2020, 35, 1484-1498.

45. Carlos, N.R.; Jaime, T.; Philip, T.; Andy, J.; Julian, R.V. High-resolution and bias-corrected CMIP5 projections for climate change impact assessments. Sci. Data 2020, 7, 1-14.

46. Emori, S.; Taylor, K.; Hewitson, B.; Zermoglio, F.; Juckes, M.; Lautenschlager, M.; Stockhause, M. CMIP5 data provided at the IPCC Data Distribution Centre. Clim. Chang. 2016, 1-8. Available online: https://www.ipcc-data.org/docs/factsheets/TGICA_ Fact_Sheet_CMIP5_data_provided_at_the_IPCC_DDC_Ver_1_2016.pdf (accessed on 7 March 2021).

47. Taylor, K.E.; Stouffer, R.J.; Meehl, G.A. An Overview of CMIP5 and the Experiment Design. Bull. Am. Meteorol. Soc. 2012, 93, 485-498. [CrossRef]

48. Moss, R.H.; Edmonds, J.A.; Hibbard, K.A.; Manning, M.R.; Rose, S.K.; van Vuuren, D.P.; Carter, T.R.; Emori, S.; Kainuma, M.; Kram, T; et al. The next generation of scenarios for climate change research and assessment. Nature 2010, 463, 747-756. [CrossRef] [PubMed]

49. IPCC. Managing the Risks of Extreme Events and Disasters to Advance Climate Change Adaptation (SREX); Intergovernmental Panel on Climate Change: Geneva, Switzerland, 2011.

50. Liang, C.; Frauenfeld, O.W. Surface Air Temperature Changes over the Twentieth and Twenty-First Centuries in China Simulated by 20 CMIP5 Models. JCli 2014, 27, 3920-3937.

51. Chen, A.F.; Feng, Q.; Zhang, J.K.; Li, Z.X.; Wang, G. A Review of Climate Change Scenario for Impacts Process Study. Sci. Geogr. Sin. 2015, 35, 84-90.

52. Chen, X.C.; Xu, Y.; Xu, C.H.; Yao, Y. Assessment of Precipitation Simulations in China by CMIP5 Multi-models. Clim. Chang. Res. 2014, 10, 217-225.

53. Julian, R.V.; Andy, J. Downscaling Global Circulation Model Outputs: The Delta Method Decision and Policy Analysis. Work. Pap. 2010, 1, 1-18.

54. Hu, Z.Z.; Gao, C.X. Improvement of the Com prehensive and SequentialClassification System of Grasslands 1 Indices ofGrassland Classes and Index Chart. Acta Pratacult. Sin. 1995, 4, 1-7.

55. Sheng, F.Q. Characteristics of Spatio-Temporal Distribution of Global and Regional Vegetable Types Based on CSCS Model; LanZhou Univeristy: Lanzhou, China, 2012.

56. Prentice, I.C.; Cramer, W.; Harrison, S.P.; Leemans, R.; Monserud, R.A.; Solomon, A.M. A global biome model based on plant physiology and dominance, soil properties and climate. J. Biogeogr. 1992, 19, 117-134. [CrossRef]

57. Cohen, J. A Coefficient of Agreement for Nominal Scales. Educ. Psychol. Meas. 1960, 20, 37-46. [CrossRef]

58. Yates, D.N.; Kittel, T.G.F.; Cannon, R.F. Comparing the Correlative Holdridge Model to Mechanistic Biogeographical Models for Assessing Vegetation Distribution Response to Climatic Change. Clim. Chang. 2000, 44, 59-87. [CrossRef]

59. Zhao, D.S.; Wu, S.H. Vulnerability of natural ecosystem in China under regional climate scenarios: An analysis based on eco-geographical regions. J. Geogr. Sci. 2014, 24, 237-248. [CrossRef]

60. Aleman, J.C.; Blarquez, O.; Gourlet-Fleury, S.; Bremond, L.; Favier, C. Tree cover in Central Africa: Determinants and sensitivity under contrasted scenarios of global change. Sci. Rep. 2017, 7, 41393. [CrossRef] 